\title{
Citric Acid as an Alternative to Sulfuric Acid for the Hard-Anodizing of AA6061
}

\author{
José Cabral-Miramontes ${ }^{1}$ * , Facundo Almeraya-Calderón ${ }^{1, * \mathbb{D}}$, Francisco Estupinán López ${ }^{1}$, María Lara Banda ${ }^{1}$, \\ Javier Olguín-Coca ${ }^{2}$, Luis Daimir López-León ${ }^{2}$ (D), Ivan Castañeda-Robles ${ }^{2}$, Miguel Ángel Esneider Alcalá ${ }^{3}$, \\ Patricia Zambrano-Robledo ${ }^{1}$ (D) and Citlalli Gaona-Tiburcio ${ }^{1, * \mathbb{D}}$
}

check for

updates

Citation: Cabral-Miramontes, J.; Almeraya-Calderón, F.; López, F.E.; Lara Banda, M.; Olguín-Coca, J.; López-León, L.D.; Castañeda-Robles, I.; Alcalá, M.Á.E.; Zambrano-Robledo, P.; Gaona-Tiburcio, C. Citric Acid as an Alternative to Sulfuric Acid for the Hard-Anodizing of AA6061. Metals 2021, 11, 1838. https://doi.org/ $10.3390 /$ met11111838

Academic Editor: Changdong Gu

Received: 21 September 2021

Accepted: 10 November 2021

Published: 16 November 2021

Publisher's Note: MDPI stays neutral with regard to jurisdictional claims in published maps and institutional affiliations.

Copyright: (c) 2021 by the authors. Licensee MDPI, Basel, Switzerland. This article is an open access article distributed under the terms and conditions of the Creative Commons Attribution (CC BY) license (https:// creativecommons.org/licenses/by/ $4.0 /)$.
1 Universidad Autónoma de Nuevo León, FIME-Centro de Investigación e Innovación en Ingeniería Aeronáutica (CIIIA), Av. Universidad s/n, Ciudad Universitaria, San Nicolás de los Garza 66455, Mexico; francisco.estupinanlop@uanl.edu.mx (F.E.L.); maria.laraba@uanl.edu.mx (M.L.B.); patricia.zambranor@uanl.edu.mx (P.Z.-R.)

2 Universidad Autónoma del Estado de Hidalgo, Área Académica de Ingeniería y Arquitectura, Carretera Pachuca-Tulancingo Km. 4.5, Hidalgo 42082, Mexico; olguinc@uaeh.edu.mx (J.O.-C.); luis_lopez@uaeh.edu.mx (L.D.L.-L.); ivan_castaneda@uaeh.edu.mx (I.C.-R.)

3 Centro de Investigación en Materiales Avanzados Subsede Monterrey (CIMAV), Alianza Norte 202, PIIT, Autopista Monterrey-Aeropuerto, Km 10, Apodaca 66628, Mexico; miguel.esneider@cimav.edu.mx

* Correspondence: jose.cabralmr@uanl.edu.mx (J.C.-M.); facundo.almerayacld@uanl.edu.mx (F.A.-C.); citlalli.gaonatbr@uanl.edu.mx (C.G.-T.)

\begin{abstract}
Hard-anodized is a widely used method in the aeronautical sector to improve aluminum alloys abrasion and corrosion resistance. Aim of this work was to characterize the mechanical properties and resistance hard-anodized aluminum 6061 in citric acid solution as a replacement sulfuric acid solution were investigated. Aluminum alloy 6061 was used as the base material to produce the hard anodizing; this process was carried out in a citric and sulfuric acid solution, applying current densities 3 and $4.5 \mathrm{~A} / \mathrm{cm}^{2}$ and subsequently exposed to $3.5 \mathrm{wt}$. \% $\mathrm{NaCl}$ solution. Microstructure and mechanical properties of the anodizing material were characterized by scanning electron microscopy (SEM) and Vickers microhardness (HV). Corrosion behavior of the hard-anodized material it was carried out with electrochemical techniques as cyclic potentiodynamic polarization (CPP) and electrochemical impedance spectroscopy (EIS) respectively. Results obtained indicated that all samples anodized in citric acid solution showed negative hysteresis and lower corrosion current density $\left(1 \times 10^{-10} \mathrm{~A} / \mathrm{cm}^{2}\right)$, indicating generalized corrosion on the material surface. EIS results show that anodizing in citric acid solution and a current density of $4.5 \mathrm{~A} / \mathrm{dm}^{2}$ provides better corrosion protection than a sulfuric acid solution.
\end{abstract}

Keywords: aluminum alloy; corrosion; EIS; environmentally friendly; citric acid

\section{Introduction}

Aluminum and its alloys have many applications in aeronautical, aerospace technology, automotive industries, construction machinery, equipment, and transportation. Aluminum alloys can contact the atmosphere and naturally form a nanometric aluminum oxide layer [1-4]. Anodizing is an electrochemical process that is performed to form a protective oxide layer on the surface of a metal. Low cost, more precise thickness control and more accessible processes handling can be given as examples of these advantages [5]. Anodizing, which produces an outer porous array of columnar hexagonal cells that are normal to the substrate surface and separated by a barrier layer [6], can offer high corrosion resistance $[7,8]$. The diameter of the pores and the corrosion resistance are characteristics of anodized alloys and depend on the electrolyte used, time, and current density [9-13]. The anodizing process can be carried out in different acid electrolytes, and they are classified into three groups: inorganic, organic carboxylic, and organic cyclic oxocarbon. [10-13]. 
The main variables of the hard anodizing process are current density, anodizing time, solutions used for the process, and additives, among others. Based on these variables, some of the critical characteristics of the alumina film formed can be controlled, such as the thickness, porosity, and structure. The aluminum anodizing process is classified into three main types. Each of them uses different solutions to generate the alumina film, that is, chromic acid (type I), sulfuric acid (type II), and sulfuric acid, and different additives such as oxalic and sulfosalicylic acid for hard anodizing (type III). Each one presents different thicknesses ranging from 1 to $7 \mu \mathrm{m}$ for type I, 2 to $25 \mu \mathrm{m}$ for type II, and 12 to $114 \mu \mathrm{m}$ for type III. For Type III, the hardness values are between 60 and 65 HRC [14-16].

The hard anodized coatings are of paramount importance in engineering industries such as aeronautical, where high wear resistance and corrosion resistance surfaces are required, such as pistons, cylinders, hydraulic gears, sensors due to their insulating properties, etc. [17-20].

Some of the leading industrial applications of type III hard anodizing are in the aeronautical, automotive, and electronic sectors [21-24].

Due to its nature-friendly properties and low cost, hard anodizing has become a point of interest in the last century. Increasingly stringent environmental regulations in different industry sectors, especially the aeronautical industry, suggest more investigations regarding the effect of environmentally friendly corrosion protective processes.

In recent years, some alternatives to sulfuric acid have been used for hard anodizing. While less dangerous than chromic acid, it is still a hazardous chemical to handle, with worrying environmental effects [25-28]. Different countries have made efforts to manufacture hard anodizing with other substances such as metallic cations, organic acids, and mixtures of sulfuric and chromic acid used as electrolytes. All this is to achieve greater stability and complexity of the crystalline structure of the anodized coating, thereby increasing corrosion resistance. Citric acid is one of the most used organic acids as an additive since it forms complex compounds with $\mathrm{Al}^{3+}$. The most common reaction mechanisms are due to the formation of tough compounds between aluminum and organic molecules. The insoluble metal complexes in the soaps form incorporated into the surface of the anodic coating are based on the reactions between the carboxylates of hard ions with cations of $\mathrm{Al}^{3+}$. Complex additives include thin layers on the surface of the oxide, protecting the base metal and providing process stability [29,30]. Citric acid is one of the safest and most environmentally friendly materials according to the Environmental Protection Agency (EPA-SCIL), which allows it to be used as an electrolyte in the anodizing process, replacing sulfuric acid [31].

In the present work, the mechanical properties and the corrosion behavior of eight different types of hard anodizing were manufactured with solutions composed in its highest proportion of citric acid with small additions of sulfuric acid (5 and $10 \mathrm{~mL} / \mathrm{L}$ ) current densities of 3 and $4.5 \mathrm{~A} / \mathrm{dm}^{2}$, were investigated. Scanning electron microscopy, Vickers microhardness, cyclic potentiodynamic polarization curves, and electrochemical impedance spectroscopy, was used to evaluate the properties of the coatings. The aim of this work was total replacement sulfuric acid with citric acid in type III hard anodizing manufacturing process make an environmentally friendly process.

\section{Materials and Methods}

\subsection{Materials}

Aluminum alloy 6061 specimens of a diameter of $50 \mathrm{~mm}$ and thickness of $5 \mathrm{~mm}$ dimensions were used in the present study. The chemical composition of the AA6061 was obtained by X-ray fluorescence (Olympus DELTA XRF., Richmond, TX, USA).

\subsection{Anodizing Process}

Before anodization, aluminum alloy AA6061 was polished using different SiC grit papers with 180, 320, 400, and 600 grades.

The anodizing process consisted of the following stages [32,33].

$>$ Degreased and pickling for $5 \mathrm{~s}$ in $50 \mathrm{wt}$. \% $\mathrm{HCl}$ solution. 
$>$ Three rinses in deionized water, each of $3 \mathrm{~s}$ duration.

$>$ Anodizing Bath:

- $2 \mathrm{M}$ sulfuric acid solution (196 g/L of $\left.\mathrm{H}_{2} \mathrm{SO}_{4}\right)$.

- $1 \mathrm{M}$ citric acid solution (192 g/L) with the addition of sulfuric acid of 5 and $10 \mathrm{~mL} / \mathrm{L}$.

- $2 \mathrm{M}$ citric acid solution ( $384 \mathrm{~g} / \mathrm{L}$ ) with the addition of sulfuric acid of 5 and $10 \mathrm{~mL} / \mathrm{L}$.

- $\quad$ The current generator used was a Model XLN30052-GL High Power Programmable DC Power Supply with a capacity of 300 Volts (V) and 5 Amperes (A). Current densities used, 3 and $4.5 \mathrm{~A} / \mathrm{dm}^{2}$

- Time $60 \mathrm{~min}$.

- $\quad$ Temperature at $5{ }^{\circ} \mathrm{C} \pm 2{ }^{\circ} \mathrm{C}$.

$>$ Rinse in deionized water for $5 \mathrm{~s}$.

$>$ Sealing treatment, in $\mathrm{H}_{2} \mathrm{O}$ solution at $95{ }^{\circ} \mathrm{C}$ for $60 \mathrm{~min}$.

The samples nomenclature and variables used in the anodizing process are shown in Table 1.

Table 1. Process parameters and nomenclature of the AA6061 samples.

\begin{tabular}{|c|c|c|c|c|c|c|}
\hline \multirow{3}{*}{ Alloy } & \multicolumn{4}{|c|}{ Anodizing } & \multirow{3}{*}{ Sealing } & \multirow{3}{*}{ Nomenclature } \\
\hline & \multicolumn{2}{|c|}{ Bath } & \multirow{2}{*}{$\begin{array}{l}\text { Current Density } \\
\left(\mathrm{A} / \mathrm{dm}^{2}\right)\end{array}$} & \multirow{2}{*}{ Time (min) } & & \\
\hline & Citric Acid & Sulfuric Acid & & & & \\
\hline \multirow{10}{*}{ AA6061 } & - & $2 \mathrm{M}$ & \multirow{5}{*}{3} & \multirow{5}{*}{60} & \multirow{5}{*}{$\begin{array}{c}\text { Deionized } \\
\text { water at } 95^{\circ} \mathrm{C} \\
\text { for } 60 \mathrm{~min}\end{array}$} & 3A C0M S2M \\
\hline & $1 \mathrm{M}$ & $5 \mathrm{~mL} / \mathrm{L}$ & & & & 3A C1M S5 \\
\hline & $1 \mathrm{M}$ & $10 \mathrm{~mL} / \mathrm{L}$ & & & & 3A C1M S10 \\
\hline & $2 \mathrm{M}$ & $5 \mathrm{~mL} / \mathrm{L}$ & & & & 3A C2M S5 \\
\hline & $2 \mathrm{M}$ & $10 \mathrm{~mL} / \mathrm{L}$ & & & & 3A C2M S10 \\
\hline & - & $2 \mathrm{M}$ & \multirow{5}{*}{4.5} & \multirow{5}{*}{60} & \multirow{5}{*}{$\begin{array}{c}\text { Deionized } \\
\text { water at } 95^{\circ} \mathrm{C} \\
\text { for } 60 \mathrm{~min}\end{array}$} & 4.5A C0M S2M \\
\hline & $1 \mathrm{M}$ & $5 \mathrm{~mL} / \mathrm{L}$ & & & & 4.5A C1M S5 \\
\hline & $1 \mathrm{M}$ & $10 \mathrm{~mL} / \mathrm{L}$ & & & & 4.5A C1M S10 \\
\hline & $2 \mathrm{M}$ & $5 \mathrm{~mL} / \mathrm{L}$ & & & & 4.5A C2M S5 \\
\hline & $2 \mathrm{M}$ & $10 \mathrm{~mL} / \mathrm{L}$ & & & & 4.5A C2M S10 \\
\hline
\end{tabular}

\subsection{Microstructural Characterization}

Microstructural analysis was performed with a scanning electron microscope (SEM, Jeol JSM 6510LV, Tokyo, Japan). Surface and cross-sections micrographs of the AA6061 sample were made to determine the thickness of the anodic layer at $2000 \times$ magnifications, operating at $20 \mathrm{kV}$ and $\mathrm{WD}=12 \mathrm{~mm}$. The specimens were polished using metallographic techniques according to ASTM E3 and E407 standards [34,35]. The material was polishing using different $\mathrm{SiC}$ grit papers with $400-4000$ grades, followed by ultrasonic cleaning in ethanol and deionized water.

\subsection{Vickers Microhardness (HV)}

Vickers microhardness was measured in cross-section of hard anodized coating in a microhardness tester (Wilson Tester 402 MVD, Lake Bluff, IL, USA), using a load 0.05 gf and dwell time of $15 \mathrm{~s}, 15$ readings per sample were performed.

\subsection{Corrosion Test}

A standard three-electrode cell was used composed of platinum as a counter electrode, working electrode (AA6061), and saturated calomel electrode (SCE) as reference electrodes. An area of $100 \mathrm{~mm}^{2}$ was exposed to the electrolytes [36-38].

The corrosion resistance of the anodized samples was investigated using cyclic potentiodynamic polarization (CPP) and electrochemical impedance spectroscopy (EIS) [38]. 
Corrosion tests were conducted at room temperature using a potentiostat/galvanostat Gill-AC from ACM Instruments (Manchester, UK), in $3.5 \mathrm{wt}$ \% \% NaCl solution. For each sample, CPP tests were performed in the range of -0.30 to $+1.0 \mathrm{~V}$ vs. open circuit potential (OCP) at a constant scan rate of $0.06 \mathrm{~V} / \mathrm{m}$, using a complete polarization cycle [39-41]. EIS measurements were performed in the frequency range of $0.01-100,000 \mathrm{~Hz}$, and the perturbation amplitude was $10 \mathrm{mV}$ in the mentioned solution [42]. The spectra of EIS were analyzed in terms of an equivalent circuit using "Zview" software (AMETEK Scientific Instruments, Oak Ridge, TN, USA). All the corrosion tests were performed in triplicate.

\section{Results}

\subsection{Chemical Composition}

The chemical composition (see Table 2) of the AA6051 was obtained by X-ray fluorescence. The aluminum composition corresponds to the proposed by different authors [43]. This low copper or silicon content aluminum alloy produces the best results with anodization as the pure aluminum alloy approaches pure aluminum, the coatings' density and hardness increase while the surface finishes' roughness decreases [44,45].

Table 2. Chemical composition of aluminum alloy AA6061 by X-ray fluorescence (wt. \%).

\begin{tabular}{cccccccccc}
\hline Elements & Al & $\mathbf{C u}$ & $\mathbf{M g}$ & $\mathbf{M n}$ & $\mathbf{F e}$ & $\mathrm{Si}$ & $\mathbf{Z n}$ & $\mathbf{C r}$ & Ti \\
\hline 6061 & Bal. & $0.08 \pm 0.004$ & $2.14 \pm 0.107$ & $0.03 \pm 0.0015$ & $0.11 \pm 0.0055$ & $2.14 \pm 0.107$ & $0.15 \pm 0.0075$ & $0.12 \pm 0.006$ & $0.08 \pm 0.004$ \\
\hline
\end{tabular}

\subsection{Microstructural Characterization (SEM) \\ 3.2.1. Surface Morphology}

Figures 1 and 2 show the surface morphology obtained by SEM for samples anodized at different current densities, i.e., 3 and $4.5 \mathrm{~A} / \mathrm{dm}^{2}$ in different bath solutions. All the samples manufactured with a current density of $3 \mathrm{~A} / \mathrm{dm}^{2}$ and the different anodizing solutions presented porosity and surface cracks. The samples anodized in $2 \mathrm{M}$ sulfuric acid solutions presented a more homogeneous surface with less porosity and defects such as cracks (Figure 1a). In anodizing with a current density of $4.5 \mathrm{~A} / \mathrm{dm}^{2}$, the different citric and sulfuric acid baths presented surface morphology with cracks and pores (Figure 2). This same phenomenon is observed in the sample anodized only with $2 \mathrm{M}$ sulfuric acid (Figure 2a). For the current density of $4.5 \mathrm{~A} / \mathrm{dm}^{2}$, the sample with the highest surface homogeneity was $4.5 \mathrm{C} 1 \mathrm{M} \mathrm{S10}$, presenting less porosity and cracking. All the anodized samples in the different solutions and different baths composed of citric acid and sulfuric acid showed superficial cracks and porosity. Tertiary acid also produces this type of structure, as has been observed in other works [46]. Additionally, boric acid used in AA1050 and AA20242 T3 aluminum alloys has produces similar surface morphologies [47].

\subsubsection{Cross-Sectional Morphology}

Figures 3 and 4 show SEM cross-sectional micrographs of the samples anodized. For the anodized with a current density of $3 \mathrm{~A} / \mathrm{dm}^{2}$, with different baths in the cross-section, no cracks or distributed porosity were observed in the coatings; only the sample 3A C0M S2M presented porosity inside the coating (Figure 3a). In the samples manufactured with a current density of $4.5 \mathrm{~A} / \mathrm{dm}^{2}$, in the different baths composed of citric and sulfuric acid, no porosity or cracking from the surface was observed, and that could reach the substrate (Figure 4), again, only the 4.5A C0M S2M sample presented cracks and porosity. However, the cracking did not match the surface of the substrate, only occurring superficially (Figure 4a). Microcracks typical and characteristic of hard-anodized surfaces are observed in different solutions and current densities of prepared hard anodic coatings [33]. The sealing process produces thermal stresses caused by the different coefficients of thermal expansion of the anodic coating and the metallic substrate, which can cause pores and cracks in the surface of the material. Mechanical preparation for cross-sectional metallography 
can also induce mechanical stresses that manifest as cracks and pores [48]. Porosity and cracks were not observed in the samples anodized with citric and sulfuric acid solutions.
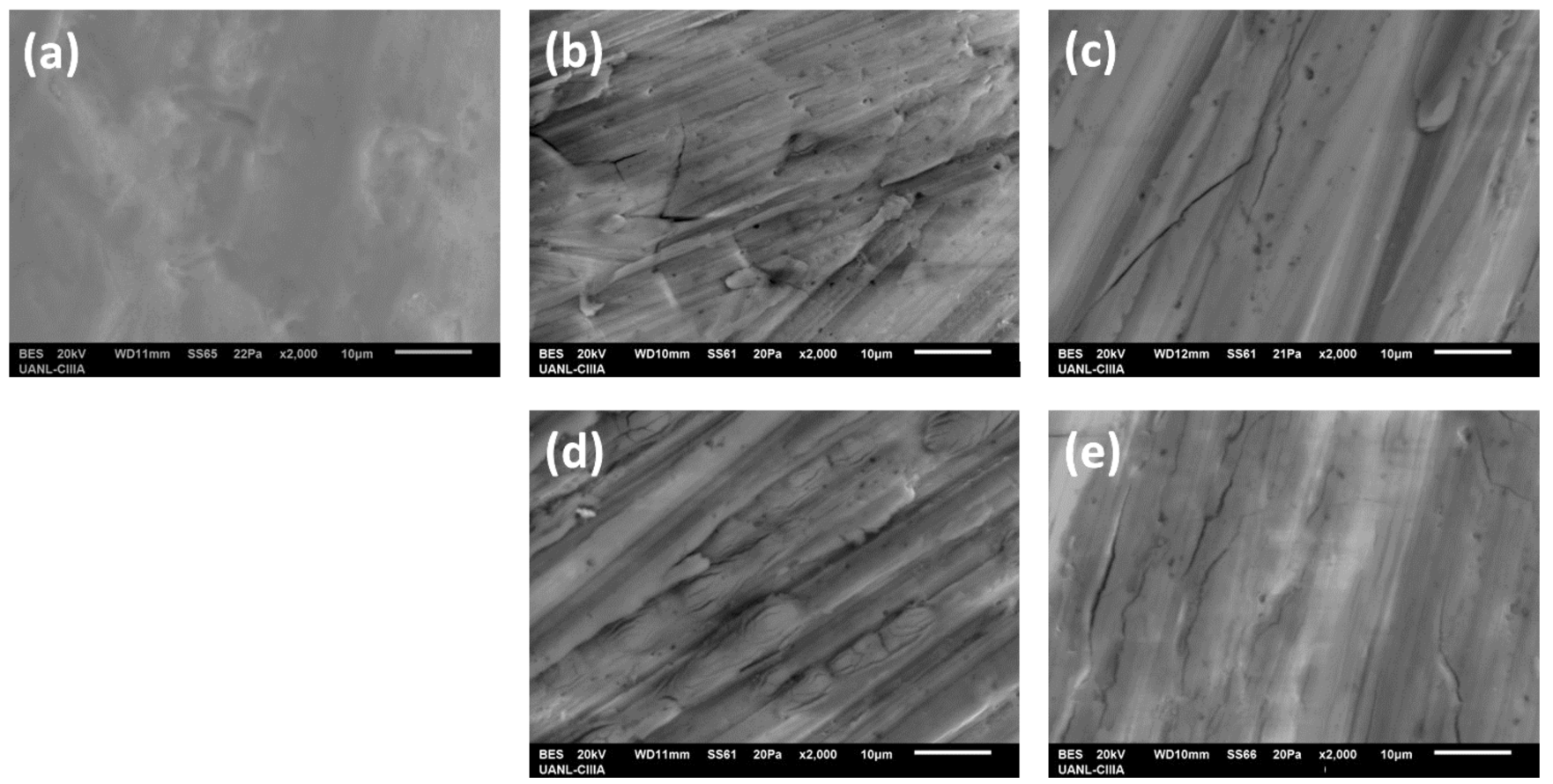

Figure 1. SEM surface morphology of the AA6061 anodized a $3 \mathrm{~A} / \mathrm{dm}^{2}$ in different baths: (a) 3A C0M S2M, (b) 3A C1M S5, (c) 3A C1M S10, (d) 3A C2M S5 and (e) 3A C2M S10.
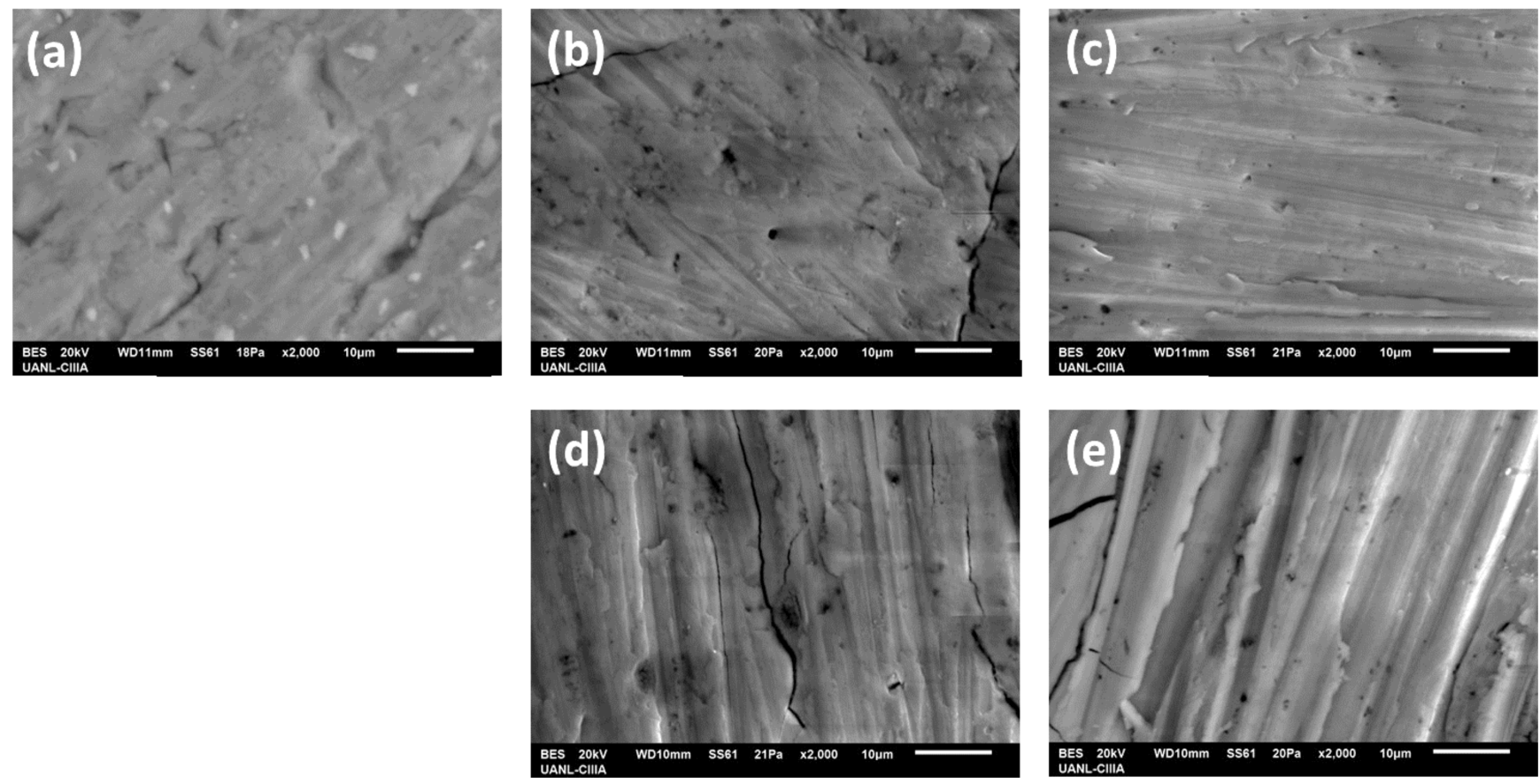

Figure 2. SEM Surface morphology of the AA6061 anodized a $4.5 \mathrm{~A} / \mathrm{dm}^{2}$ in different bath: (a) 4.5A C0M S2M, (b) 4.5A C1M S5, (c) 4.5A C1M S10, (d) 4.5A C2M S5 and (e) 4.5A C2M S10. 

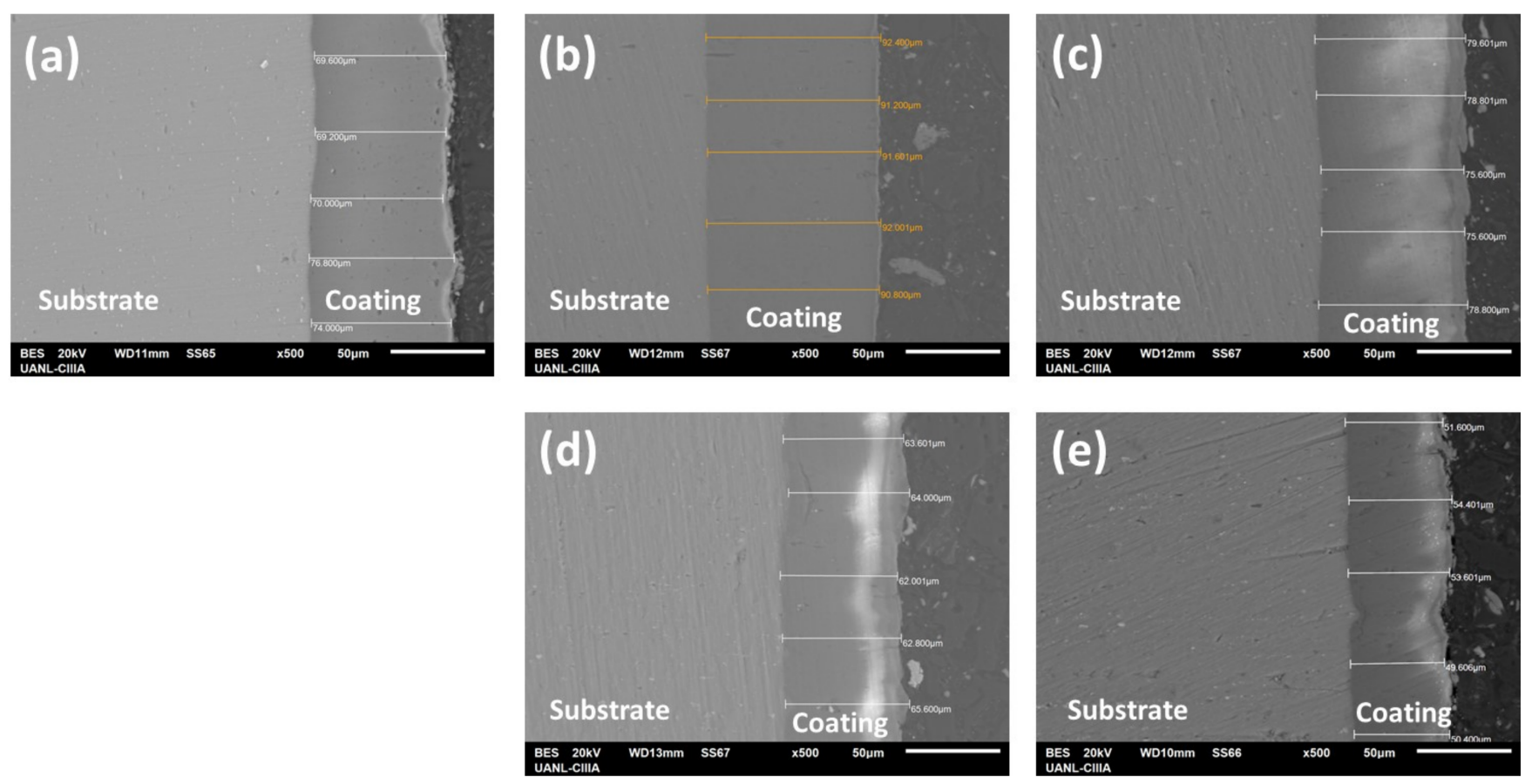

Figure 3. SEM Cross-Sectional Micrographs of the AA6061 Anodized a $3 \mathrm{~A} / \mathrm{dm}^{2}$ in Different Bath: (a) 3A C0M S2M, (b) 3A C1M S5, (c) 3A C1M S10, (d) 3A C2M S5 and (e) 3A C2M S10.
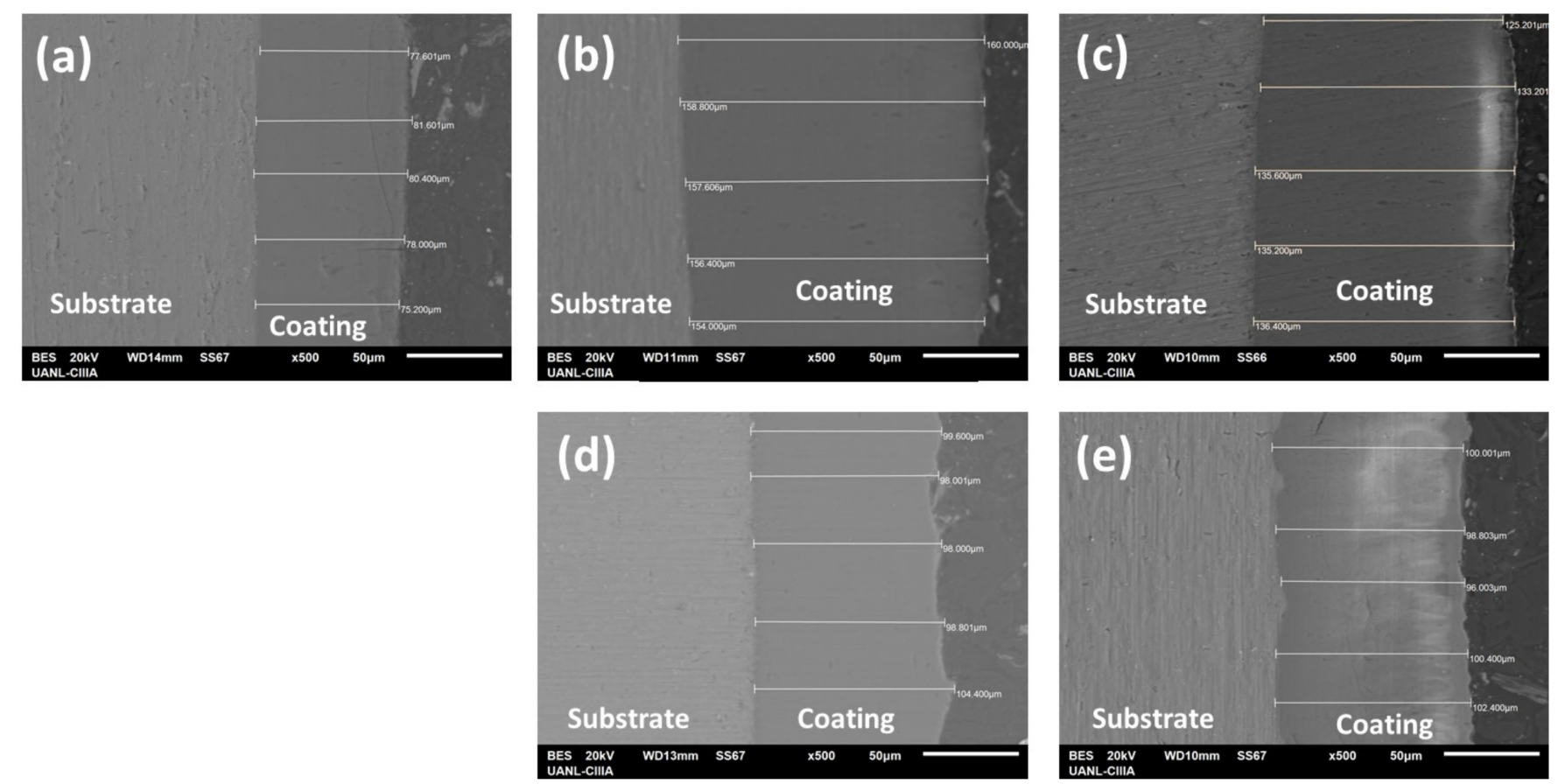

Figure 4. SEM Cross-Sectional Micrographs of the AA6061 Anodized a 4.5 A/dm² in Different Bath: (a) 4.5A C0M S2M, (b) 4.5A C1M S5, (c) 4.5A C1M S10, (d) 4.5A C2M S5 and (e) 4.5A C2M S10.

\subsubsection{Thickness of Anodized Materials}

Figure 5 shows the thickness obtained by SEM in cross-sectional micrographs for samples anodized at different current densities, i.e., 3 and $4.5 \mathrm{~A} / \mathrm{dm}^{2}$ in different bath solutions composed of citric and sulfuric acid. The anodized samples in a current density of $3 \mathrm{~A} / \mathrm{dm}^{2}$ presented lower coating thicknesses, with thicknesses that vary between 50 and $90 \mu \mathrm{m}$. This behavior is because the oxidation film's growth rate makes the process 
unprofitable if shallow current density values are handled. However, when the current density reaches its maximum limit, it will acquire an adverse result. The excessively high current density will enlarge the porosity's heat effect and accelerate the dissolution of oxidation film $[49,50]$. For the anodized samples in a current density of $4.5 \mathrm{~A} / \mathrm{dm}^{2}$, the thicknesses varied between 80 and $155 \mu \mathrm{m}$. The variation thickness is due to the applied current density directly affecting the oxidation film's growth rate, and whether the optimum value is exceeded may reduce the film thickness. In addition, the samples anodized with $2 \mathrm{M}$ citric acid solution and different sulfuric acid aggregates, i.e., 5 and $10 \mathrm{~mL} / \mathrm{L}$, presented less thickness regardless of the anodizing current density used. It has been reported that when working with low concentrations of sulfuric acid in the anodizing solution, a significant dissolution of the anodic layer formed is caused [50]. The electrolyte is chosen to carry out an anodizing process that significantly influences the resultant anodic alumina film. The type of electrolyte, its concentration, and its temperature will determine some of the film characteristics [51-53]. In general, the thickness obtained in the different anodizing conditions made it possible to achieve thicknesses greater than $12.7 \mu \mathrm{m}$, which is the minimum thickness required by the military regulations (Mil-A-8625) for type III hard anodizing [16].

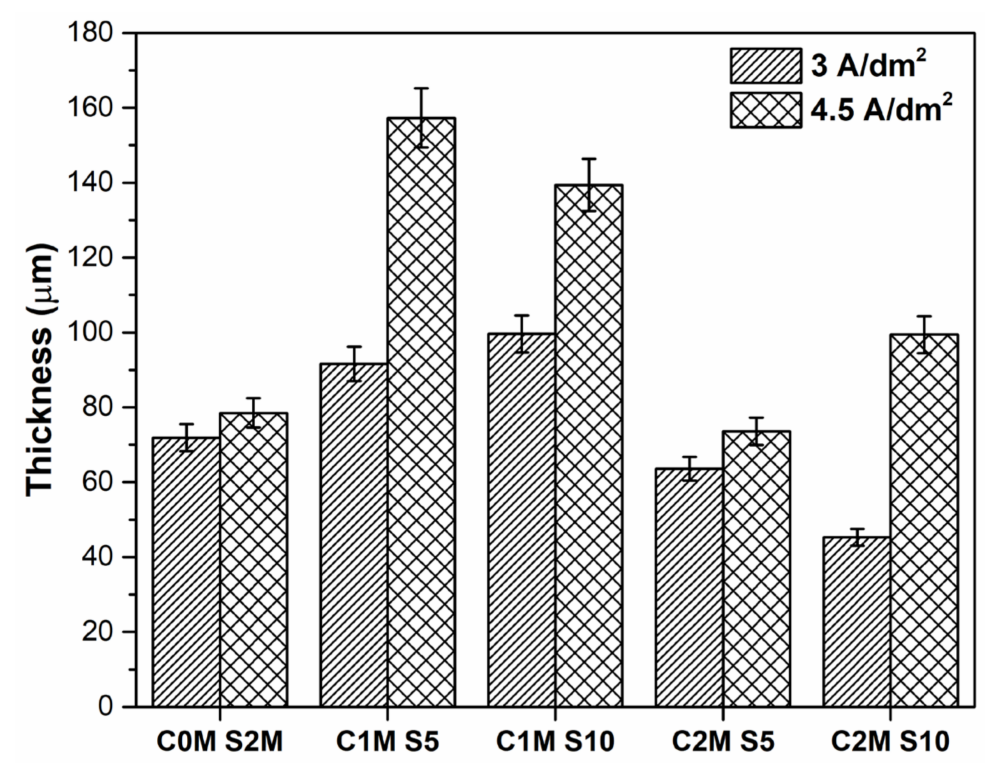

Figure 5. The thickness of the coatings of the samples anodized with current densities of 3 and $4.5 \mathrm{~A} / \mathrm{dm}^{2}$ in different baths.

\subsection{Vickers Microhardness (HV)}

Vickers microhardness of all anodized samples was measured in a cross-section of coatings, and the results are presented in Figure 6. In this work, all the anodized samples presented microhardness greater than the non-anodized material, regardless of the solution and the anodized current density used. The anodized samples with a current density of $3 \mathrm{~A} / \mathrm{dm}^{2}$ showed higher microhardness than those with a current density of $4.5 \mathrm{~A} / \mathrm{dm}^{2}$. This effect is mainly due to dilute electrolytes. Low temperatures favor the growth of harder films. In contrast, more concentrated electrolytes and high temperatures, and long process times factors that will favor the dissolution of the film in the electrolyte may produce soft, powdery, spongy, or easily rubbed off films [54].

For this reason, hard anodizing with concentrated electrolytes and high temperatures; produces nonuniform hardness and wear resistance throughout the film, the film being weaker nearer the top surface [54]. In anodized samples with a current density of $3 \mathrm{~A} / \mathrm{dm}^{2}$, the microhardness, measured on the cross-section of the coatings, increased slightly with their decreased thickness, which indicates that the thin and compact anodic layers are harder. In the anodized samples with a current density of $4.5 \mathrm{~A} / \mathrm{dm}^{2}$, a decrease in 
microhardness is noticeable, in which the lower the thickness, the lower the hardness value obtained. In this case, the hardness is more directly related to the concentrations of the electrolytes and the current used since concentrated electrolytes, high current densities, and high temperatures can produce soft, spongy, and brittle coatings [55]. For hard-anodized films, the Vickers hardness values (VHN, $\mathrm{kg} / \mathrm{mm}^{2}$ ) generally encountered are 300-500 [56], in this work, only the samples anodized at a current density of $3 \mathrm{~A} / \mathrm{dm}^{2}$ exceeded these values, on the other hand, the anodized with a current density of $4.5 \mathrm{~A} / \mathrm{dm}^{2}$ obtained lower values of microhardness. The microhardness presented by the anodized samples with a current density of $3 \mathrm{~A} / \mathrm{dm}^{2}$ could be associated with the formation of Boehmite $\left(\mathrm{Al}_{2} \mathrm{O}_{3} \cdot \mathrm{H}_{2} \mathrm{O}\right)$ with hardness between 250-600 VHN, while, for the anodized samples with a current density of $4.5 \mathrm{~A} / \mathrm{dm}^{2}$ microhardness could be associated with the formation of Bayerite $\left(\mathrm{Al}_{2} \mathrm{O}_{3} \cdot 3 \mathrm{H}_{2} \mathrm{O}\right)$ which generally has a microhardness of 150-300 VHN [57].

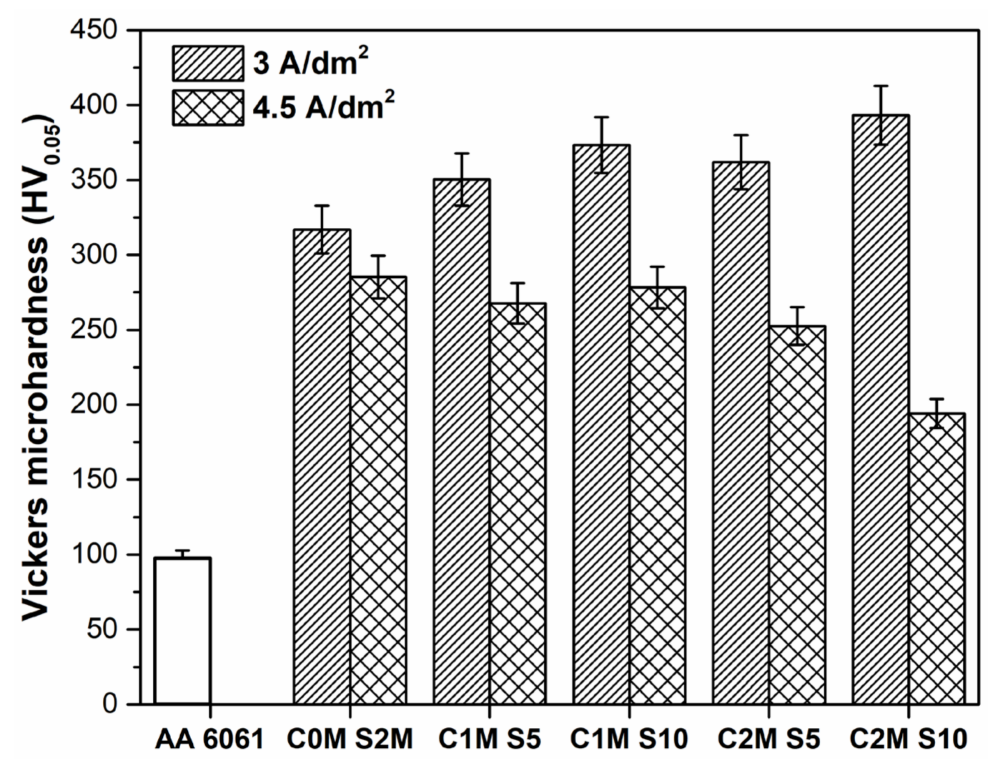

Figure 6. Vickers microhardness of non-anodized AA6061 substrate and after hard anodizing with different solutions a current density.

\subsection{Corrosion Test}

\subsubsection{Cyclic Potentiodynamic Polarization (CPP)}

The CPP behavior for the non-anodized and anodized samples with a current density of $3 \mathrm{~A} / \mathrm{dm}^{2}$ exposed in $3.5 \%$ wt $\mathrm{NaCl}$ solution is shown in Figure 7 . With this anodizing current density, all materials showed a more noble corrosion potential $\left(\mathrm{E}_{\mathrm{corr}}\right)$ than nonanodized material, which indicates that they will be less susceptible to corrosion. A more positive $\mathrm{E}_{\mathrm{corr}}$ in anodized aluminum alloys indicates a lower susceptibility to corrosion of the samples $[58,59]$. The pitting potential $\left(\mathrm{E}_{\text {pit }}\right)$ is the potential value at which the current increases, and in this potential value occurs the pitting attack. The higher $\mathrm{E}_{\text {pit }}$, the less susceptible to pitting is the aluminum. The difference between $\mathrm{E}_{\text {pit }}$ and $\mathrm{E}_{\text {corr }}$ measures the tendency to pitting onset in the material; significant differences indicate an improvement of the material resistance to pitting corrosion [60,61]. For the anodized samples 3A C0M S2M, 3A C1M S10, 3A C2M S5, and 3A C2M S10, the $E_{\text {pit }}$ values were higher than those shown by the sample without anodization, which indicates that these materials will have a greater resistance to pitting corrosion. The difference between $\mathrm{E}_{\text {pit }}$ and $\mathrm{E}_{\mathrm{corr}}$ in samples $3 \mathrm{~A}$ C0M S2M, 3A C1M S10, 3A C2M S5, and 3A C2M S10 is more significant than the material without anodizing treatment, which indicates a higher resistance to pitting corrosion.

Anodic to cathodic transition potential is the potential at which the anodic current density varies to the cathodic current density. The difference between the anodic to cathodic transition potential and $\mathrm{E}_{\mathrm{corr}}$ are used to determine the persistence of the passive film. If the anodic to cathodic transition potential is nobler than $\mathrm{E}_{\mathrm{corr}}$, the passive layer will 
not be stable if positive hysteresis is present. The passive layer will persist if the $\mathrm{E}_{\text {corr }}$ is nobler than the anodic to cathodic transition potential, presenting positive hysteresis [62]. In this sense, in the reversal curves of the anodized materials in the different solutions, the potential for anodic to cathodic transition is more negative than $\mathrm{E}_{\mathrm{corr}}$. Therefore, the passivity characteristics of the different anodized films formed during the anodizing process will remain. In the sample 3A C1M S5, due to its negative hysteresis behavior, $\mathrm{E}_{\text {pit }}$ was not present, and the potential for anodic to cathodic transition is nobler than $\mathrm{E}_{\mathrm{corr}}$, which makes it susceptible to passivation and restores the damaged oxide film. This sample is not vulnerable to pitting corrosion. The hysteresis loop of samples 3A C0M S2M and 3A C1M S5 were negative, indicating uniform corrosion. The hysteresis was positive for the AA 6061, 3A C1M S10, 3A C2M S5, and 3A C2M S10, indicating localized corrosion. The absence of the hysteresis loop for these samples in the potential sweep may mean that localized corrosion does not occur but could indicate an active surface and general corrosion. Positive hysteresis is related to pitting and crevice corrosion [63]. The corrosion parameters obtained from the CPP as $\mathrm{E}_{\mathrm{corr}}, \mathrm{E}_{\text {pit}}$, passivation current density $\left(i_{\text {pass }}\right)$, and the corrosion current density $\left(i_{\text {corr }}\right)$ are presented in Table 3 . The $i_{\text {corr }}$ and $i_{\text {pass }}$ of all anodized samples were three orders of magnitude lower than that of the substrate. The low magnitude orders indicate that Type III hard anodizing can be carried out with citric acid solutions as the main component and effectively provide corrosion protection better than the substrate without anodizing treatment. This type of behavior has also been found in 7075 aluminum alloys anodized with other systems and is mainly attributed to the barrier effect generated by anodizing [64].

Figure 8 shows CPP realized for the un-anodized and anodized material samples with a current density of $4.5 \mathrm{~A} / \mathrm{dm}^{2}$ exposed in $3.5 \mathrm{wt}$. $\% \mathrm{NaCl}$ solution. The corrosion potential of all the anodized samples with a current density of $4.5 \mathrm{~A} / \mathrm{dm}^{2}$ in the different solutions was nobler than that presented by the non-anodized material, making them less susceptible to corrosion. All the anodized samples with a current density of $4.5 \mathrm{~A} / \mathrm{dm}^{2}$ presented passivation in the anodic branch and negative hysteresis in the return curve, which indicates that these materials will have generalized corrosion. Due to all the samples negative hysteresis behavior, there was no pitting potential $\left(\mathrm{E}_{\text {pit }}\right)$. All samples presented an anodic to cathodic transition potential nobler than the $\mathrm{E}_{\mathrm{corr}}$, leading to two aspects. The first is that these samples are susceptible to show passivity and restoring the damaged oxide film, and the second is that the samples are not susceptible to pitting corrosion. A summary of the results of the cyclic potentiodynamic polarization test is given in Table 3 .

The electrochemical behavior of the anodized samples with current densities of 3 and $4.5 \mathrm{~A} / \mathrm{dm}^{2}$ in the different citric acid solutions may be due to the reactions of hard-ion carboxylates with $\mathrm{Al}^{3+}$. This reaction forms complex products incorporated into the surface, protecting it against corrosion [65]. The protective action of organic acids is dependent on their ability to adsorb onto the metal surface, thus forming a protective layer [66].

The possible surface complexing ligands in citric acid solution are $\mathrm{H}_{2} \mathrm{Cit}^{-}$, $\mathrm{HCit}^{2-}$ and $\mathrm{Cit}^{3-}$ species. The amount of these ligands in solution depends on the $\mathrm{pH}$ (e.g., in the solution of citric acid of $\mathrm{pH} 6$ prevailed $\mathrm{Hcit}^{2-}$ species). Therefore, several different surface coordination reactions occur on an aluminum oxide surface in contact with citric acid solutions, resulting in several different aluminum-citrate and/or aluminum-hydroxo-citrate surface species. The nature and the structure of these surface complexes are practically unknown. However, some authors $[67,68]$ have reported a possible two six-membered chelate ring structures of the surface. The Al-citrate complexes, that citrate anions are adsorbed on the oxide surface and incorporated into the structure of the oxide film during the anodic oxidation of aluminum in citric acid and/or citrate solutions. The general principle of possible surface coordination reactions, which occur on the surface of aluminum oxide in a solution of citric acid of $\mathrm{pH}$ range 3-6, can be illustrated by the possible surface reactions in a solution of pH 6 with Equations (1) and (2) [69-72].

$$
\mathrm{Al}-\mathrm{OH}_{2}^{+}+\mathrm{HCit}^{2-} \leftrightarrow \mathrm{AlHCit}^{-}+\mathrm{H}_{2} \mathrm{O}
$$


$\mathrm{Al}-\mathrm{OH}+\mathrm{HCit}^{2-} \leftrightarrow \mathrm{AlHCit}^{-}+\mathrm{OH}^{-}$

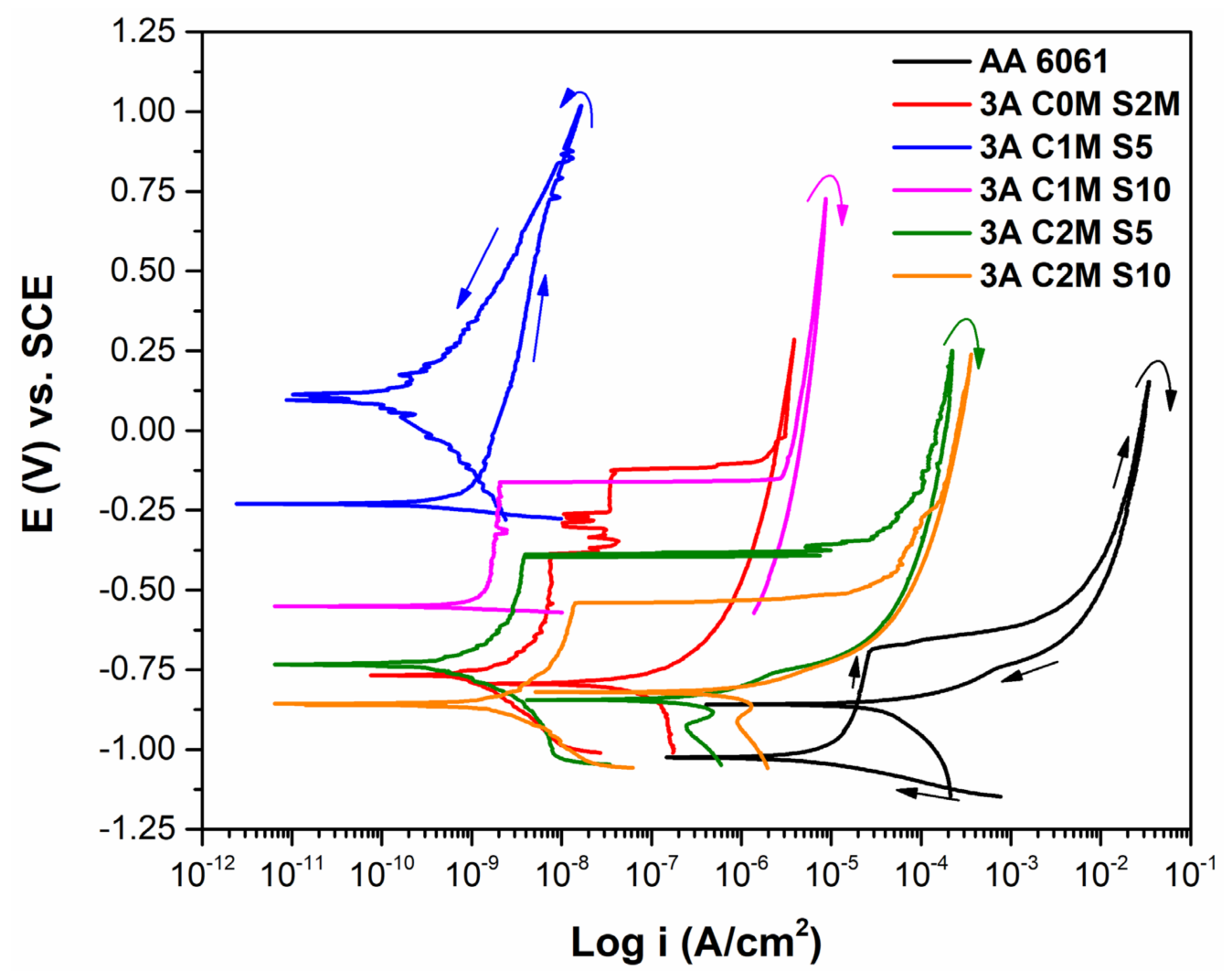

Figure 7. CPP curves of the AA6061 samples a $3 \mathrm{~A} / \mathrm{dm}^{2}$ in $\mathrm{NaCl}$ solution.

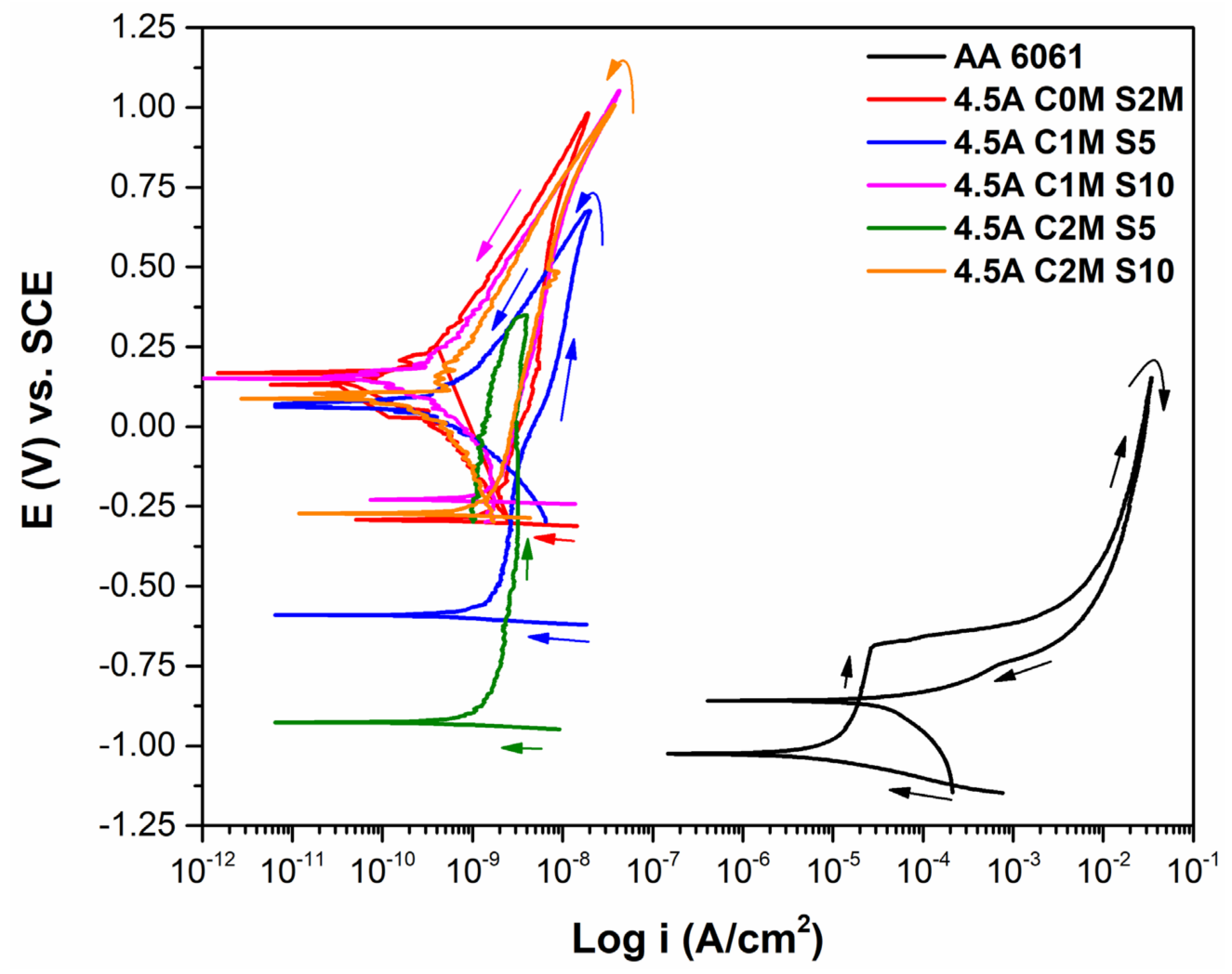

Figure 8. CPP curves of the AA6061 samples a $4.5 \mathrm{~A} / \mathrm{dm}^{2}$ in $\mathrm{NaCl}$ solution. 
The corrosion current densities are presented in Table 3. As shown in Table 3, the $\mathrm{i}_{\text {corr }}$ values are minimal, except in sample AA 6061. The dissolution (solubility) of the aluminum, Al-hydroxide, and various forms of $\mathrm{Al}$ oxide in water and non-complexing solutions is very small $[73,74]$. However, in aqueous complex-forming solutions (e.g., citrate, oxalate, salicylate), the minimum solubility is not so well expressed, and the dissolution is controlled by surface complexation reactions [70,71].

Table 3. CPP parameters of AA6061 samples in $\mathrm{NaCl}$ solution.

\begin{tabular}{|c|c|c|c|c|c|c|}
\hline Samples & $\begin{array}{c}E_{\text {corr }} \\
(\mathrm{V} \text { vs. } S C E)\end{array}$ & $\begin{array}{c}\mathrm{E}_{\text {pit }} \\
(\mathrm{V} \text { vs. } \mathrm{SCE})\end{array}$ & $\begin{array}{c}\text { E }_{\text {(Anodic to Cathodic Transition) }} \\
\text { (V vs. SCE) }\end{array}$ & $\begin{array}{c}i_{\text {pass }} \\
\left(\mathrm{A} / \mathrm{cm}^{2}\right)\end{array}$ & $\begin{array}{c}\mathbf{i}_{\text {corr }} \\
\left(\mathrm{A} / \mathrm{cm}^{2}\right)\end{array}$ & Hysteresis \\
\hline AA6061 & -1.02 & -0.689 & -0.858 & $2.22 \times 10^{-5}$ & $9.47 \times 10^{-6}$ & + \\
\hline 3A COM S2M & -0.767 & -0.124 & -0.793 & $7.41 \times 10^{-9}$ & $4.48 \times 10^{-9}$ & - \\
\hline 3A C1M S5 & -0.230 & - & 0.112 & $4.32 \times 10^{-9}$ & $3.14 \times 10^{-10}$ & - \\
\hline 3A C1M S10 & -0.551 & -0.161 & - & $2.06 \times 10^{-9}$ & $1.02 \times 10^{-9}$ & + \\
\hline 3A C2M S5 & -0.734 & -0.387 & -0.844 & $3.55 \times 10^{-9}$ & $1.57 \times 10^{-9}$ & + \\
\hline 3A C2M S10 & -0.857 & -0.540 & -0.820 & $1.30 \times 10^{-9}$ & $6.47 \times 10^{-9}$ & + \\
\hline 4.5A C0M S2M & -0.293 & - & 0.131 & $5.91 \times 10^{-9}$ & $1.27 \times 10^{-9}$ & - \\
\hline 4.5A C1M S5 & -0.590 & - & 0.065 & $4.09 \times 10^{-9}$ & $4.79 \times 10^{-10}$ & - \\
\hline 4.5A C1M S10 & -0.230 & - & 0.150 & $5.39 \times 10^{-9}$ & $1.15 \times 10^{-9}$ & - \\
\hline 4.5A C2M S5 & -0.926 & - & - & $3.16 \times 10^{-9}$ & $8.35 \times 10^{-10}$ & - \\
\hline
\end{tabular}

\subsubsection{Electrochemical Impedance Spectroscopy (EIS)}

The characteristics of EIS spectra of the specimens investigated in the present study are presented in Figures 9 and 10. EIS analysis was carried out to attain a more detailed examination of the corrosion susceptibility and protection properties of anodized materials in addition to cyclic potentiodynamic polarization curves. Figure 9a shows the Nyquist plot obtained for the un-anodized and anodized samples with a current density of $3 \mathrm{~A} / \mathrm{dm}^{2}$ and different solutions exposed in $3.5 \mathrm{wt}$. \% NaCl solution. This behavior can be seen in the zoom in the lower right of Figure 9a. This behavior can be due to an oxide layer with a constant phase element and a resistive element combination in the equivalent circuit [72]. This is the case with pure aluminum. This behavior is characteristic of aluminum alloys without anodizing treatment since they naturally form a barrier layer when in contact with oxygen from the environment $[73,74]$.

In this case, the 3A C0M S2M specimens show a capacitive loop across the entire frequency range. In the samples with different anodizing solutions, a capacitive arc was presented at high frequencies, which corresponds to the characteristics of the porous layer, and diffusion phenomena characterized by a line with a slope of $45^{\circ}$ at the lower frequencies correspond to the characteristics of the barrier layer. The two kinetic processes of the Nyquist diagrams (Figure 9) with the two-time constants present are related in the first place to the semi-passivation derived from the filling of the pores and cracks by the corrosion products formed, which diffuse towards inside the porous layer, the second time constant is associated with re-passivation of the porous layer of the coating.

The sealing of cracks in the coating is due to the formation of corrosion products that diffuse into the coating [75], which is evident by the behavior at low frequencies $(<10 \mathrm{~Hz})$ of the Nyquist diagram of Figure 9. The AA 6061 without anodizing has a lower impedance at high frequencies than the different anodized samples, generally, at high frequencies, the resistance of the coating is reflected [76]. The anodized samples in citric acid solutions show a lower corrosion rate than the non-anodized aluminum alloy, as shown by the Nyquist diagrams of Figure 9, as they present depressed semicircles in the frequency range $1 \times 10^{2}-1 \times 10^{4}$. The equivalent electrical circuits proposed to model the combination of kinetic processes from the EIS tests are shown in Figure 9b,c.

Figure 10a shows the Nyquist diagrams obtained for the AA6061 samples a $4.5 \mathrm{~A} / \mathrm{dm}^{2}$ after exposure in $3.5 \mathrm{wt}$. \% NaCl solution. Only sample 4.5A C2M S5 shows a capacitive loop for this anodizing current density across the entire frequency range. The behav- 
ior in a neutral solution of $\mathrm{NaCl} 0.1 \mathrm{M}$ of only one time constant of aluminum without anodizing and short immersion times is due to the barrier layer formed in the material naturally $[77,78]$. The Nyquist plots for samples anodized with a current density of $4.5 \mathrm{~A} / \mathrm{dm}^{2}$ present a depressed semicircle at high frequencies and a diffusion process at low frequencies. The semicircle is associated with the capacitive dispersive behavior of anodized samples. Coatings 4.5A C0M S2M, 4.5A C1M S5, 4.5A C1M S10, and 4.5A C2M S10 continuously increase impedance throughout the frequency range tested. Coating 4.5A C0M S2M and 4.5A C1M S5 have a higher impedance than the other coatings at high frequencies. It indicates that this coating has a higher impedance than all the other coatings in the frequency range tested. The proposed equivalent electrical circuits for modeling the EIS test data are presented in Figure 10b,c.
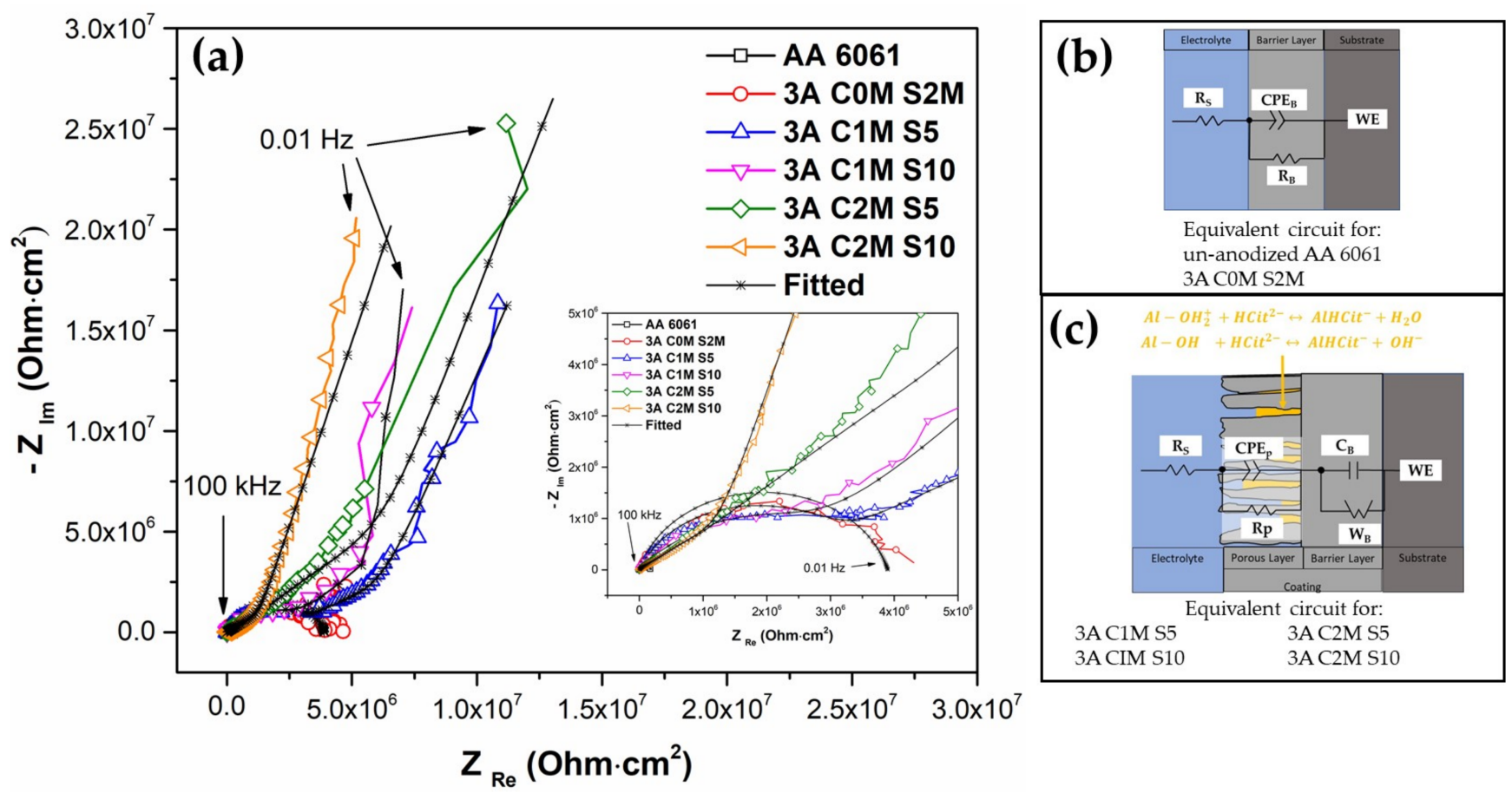

Figure 9. (a) Nyquist Diagrams in the Complex Plane to Non-Anodized and Anodized Samples a $3 \mathrm{~A} / \mathrm{dm}^{2}$ in $\mathrm{NaCl} \mathrm{Solution,}$ $(\mathbf{b}, \mathbf{c})$ Equivalent Circuits.

In Figures $9 \mathrm{a}, \mathrm{b}$ and $10 \mathrm{~b}, \mathrm{c}$, corresponding to equivalent circuits for anodized materials at 3 and $4.5 \mathrm{~A} / \mathrm{dm}^{2}, R_{s}$ is the solution resistance, $R_{p}$ is the resistance of the porous layer, and $R_{b}$ is the resistance of the barrier layer. Moreover, CPE $E_{p}$ is the constant phase element relative to the porous layer, $\mathrm{CPE}_{\mathrm{b}}$ is the continuous phase element of the barrier layer, and $\mathrm{Cb}$ is the capacitance relative to the barrier layer for some samples. $A_{p}$, and $\alpha_{B}$ is the impedance exponent to porous layer and barrier layer, respectively, and $W$ is the Warburg impedance. The CPE can represent the roughness and heterogeneity of the porous layer and the passive layer. The $\alpha$ coefficient can have several physical meanings at electrochemical interfaces, such as surface roughness, corrosion products in the porous layer, and surface heterogeneity [79-81]. The Warburg impedance explains the transfer of ions through the porous and passive layers of the coating [82]. Some authors have found that the Warburg impedance in this type of material may be since the porous layer with high thicknesses becomes brittle and initially allows the ions to pass quickly. However, when they penetrate and reach the barrier layer, they make it difficult to continue penetrating and continue to accumulate [83]. The Warburg element controls the reaction rate through the diffusion of oxidizing and reducing species to and from the metal substrate. In other words, one could have a non-linear diffusion process that originates from the geometric irregularity of 
the diffusion layers formed from the coating [84]. An increase in $\mathrm{W}$ indicates a change in corrosion kinetics from charge transfer control to diffusion control [85].

Table 4 presents the results obtained from the simulations using equivalent electrical circuits in Figures $9 b, c$ and $10 b, c$. The variation in $R_{s}$ is due to coating morphology, associated with the surface charge and the electrochemical double-layer [86]. They consider the pore resistance $\left(R_{p}\right)$ of all anodized samples with current densities of 3 and $4.5 \mathrm{~A} / \mathrm{dm}^{2}$. It can be established that this resistance also contributes to the corrosion resistance of anodized materials since $R_{p}$ is higher in most of the samples than the resistance of the barrier layer $\left(R_{b}\right)$ presented by the non-anodized material. Except for sample 4.5A C2M S10, which presented a lower resistance $R_{p}$ than the non-anodized material, it could be concluded that the anodized material in citric acid solution provides corrosion protection. The equivalent electrical circuits in Figures $9 \mathrm{~b}$ and $10 \mathrm{~b}$ represent the EIS behavior of nonanodized AA6061 aluminum evaluated in $\mathrm{NaCl}$, which consists of a resistance $\mathrm{Rb}$ and a CPEB in parallel, as the exponent value $\alpha_{B}$ is close to 1 (0.94 in Table 4 ) the CPEB can be considered as a capacitor. The higher value of $C_{B}$ for un-anodized material is attributed to a thinner barrier layer. In this sense, the $\mathrm{CPE}_{\mathrm{P}}$ and $\mathrm{C}_{\mathrm{B}}$ presented values of $1 \times 10^{-8}$ and $1 \times 10^{9} \mathrm{~F} / \mathrm{cm}^{2}$. The results indicate that the thicknesses of these layers are more significant than the barrier layer formed naturally by the material un-anodized AA 6061 (these results can be observed in Figure 9). Some authors have reported that capacitance of formed layers decreases, increasing the thickness of the formed coating [87].
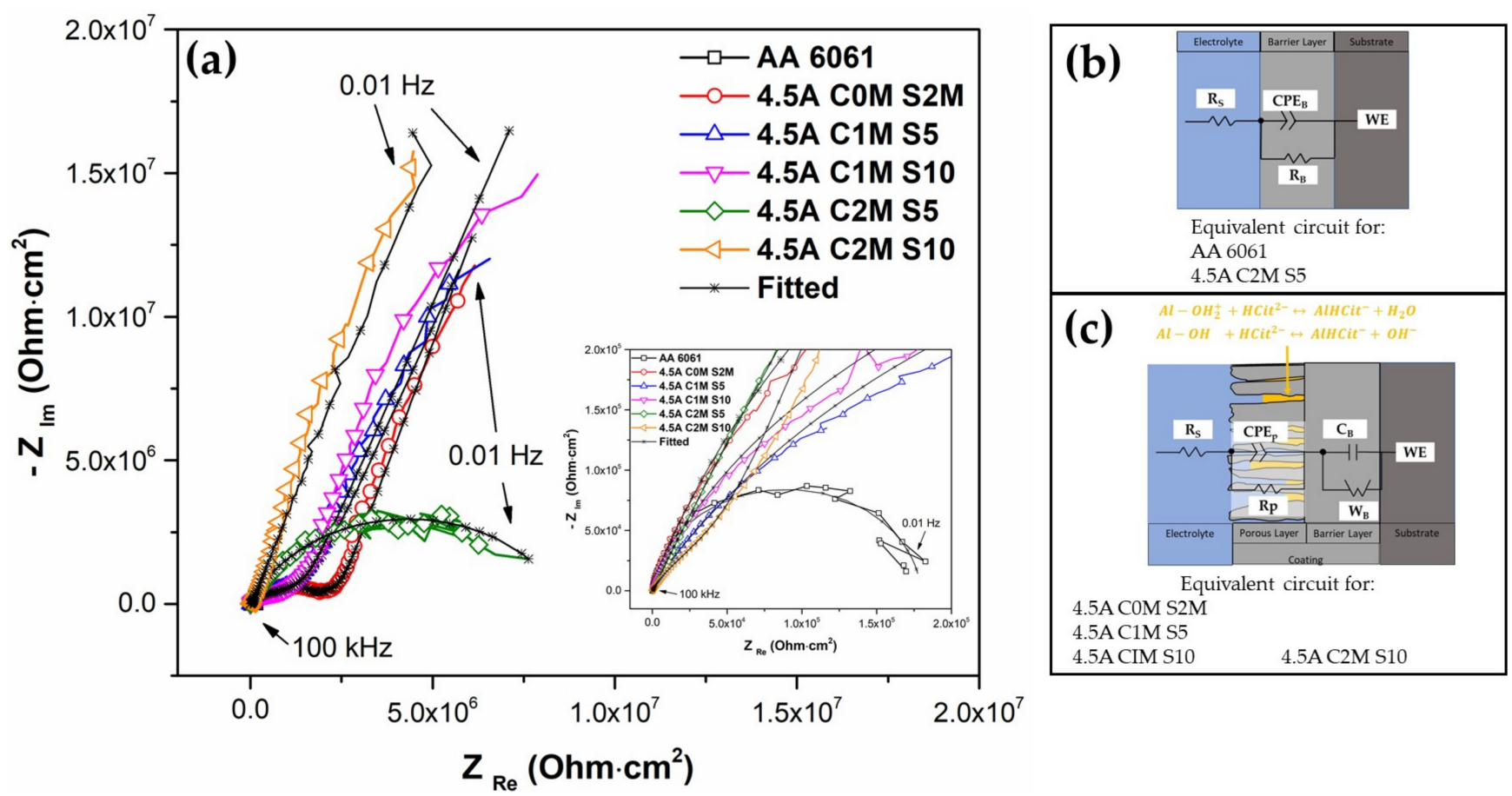

Figure 10. (a) Nyquist Diagrams to Non-Anodized and Anodized Samples a $4.5 \mathrm{~A} / \mathrm{dm}^{2}$ in NaCl Solution, (b,c) Equivalent Circuits.

The Warburg element $(\mathrm{W})$ stands for the impedance due to the transport of oxygen and metal ions across the film, this term takes account of the impedance related to the ionic transport through the oxide. It depends on the metal and oxygen ions' concentration, charge, and diffusion coefficients [88]. The larger the Warburg element (W), the greater the protection provided by the oxide film [86]. Some authors have related the Warburg impedance with the resistance that systems oppose being penetrated by diffusion mechanisms. In this case, the Warburg resistance can be taken as the resistance of oxidized species and reduced on the metal surface $[33,81,89,90]$. For this reason, $\mathrm{W}_{\mathrm{B}}$ can be taken as the corrosion resistance of anodized coatings with current densities of 3 and $4.5 \mathrm{~A} / \mathrm{dm}^{2}$ in 
the different solutions of citric-sulfuric acid. For the case where $W_{B}$ is not present, the $R_{B}$ parameter could be taken to evaluate the corrosion resistance of the anodized materials additionally with the $R_{p}$ mentioned above.

Analyzing the $\mathrm{R}_{\mathrm{B}}$ of the material un-anodizing $\left(0.17 \times 10^{6} \Omega / \mathrm{cm}^{2}\right)$, the material presented the lowest resistance to corrosion in the evaluation medium. In the samples 3A C1M S5, 3A C1M S10, and 3A C2M S5, the WB values were $8.63 \times 10^{6}, 20.60 \times 10^{6}$, and $23.90 \times 10^{6} \Omega / \mathrm{cm}^{2}$. Results indicate that the anodizing has better corrosion resistance under these conditions, which coincides with the low corrosion current densities presented by these samples in the CPP (see Figures 7 and 8 , and Table 3). However, all the $W_{B}$ values remained at values of $1 \times 10^{6} \Omega / \mathrm{cm}^{2}$. For the sample 3A C0M S2M, $R_{B}$ presented a value of $3.90 \times 10^{6} \Omega / \mathrm{cm}^{2}$ which also provides excellent protection against corrosion. It should be remembered that this sample was manufactured in a conventional solution of $\mathrm{H}_{2} \mathrm{SO}_{4}$.

In the anodized samples with a current density of $4.5 \mathrm{~A} / \mathrm{cm}^{2}$ in the different solutions of citric-sulfuric acid, the sample 4.5A C2M S5 presented an $R_{B}$ of $8.65 \times 10^{6} \Omega / \mathrm{cm}^{2}$, thereby protecting the material from corrosion. Samples 4.5A C0M S2M, 4.5A C1M S5, and 4.5A C1M S10 presented WB resistances of $2.40 \times 10^{6}, 3.31 \times 10^{6}$, and $3.00 \times 10^{6} \Omega / \mathrm{cm}^{2}$, respectively, which represents that these coatings will provide resistance to corrosion once the treatment is applied of anodizing under these conditions. Under these anodizing conditions, the sample 4.5A C2M S10 presented a WB value of $128.00 \times 10^{6} \Omega / \mathrm{cm}^{2}$, this coating being the one that presented the highest resistance to corrosion of all the samples analyzed in this work. In some other works presented of hard anodizing with a pulsed current of aluminum 6061 , have been found resistances of $2 \times 10^{5} \Omega / \mathrm{cm}^{2}$ to $10.7 \times 10^{6}$ $\Omega / \mathrm{cm}^{2}$ [90], in hard anodizing of aluminum alloys 7075 were reported resistances of $6.18 \times 10^{7}$ and $1.11 \times 10^{9} \Omega / \mathrm{cm}^{2}$ for the barrier layer [91], for anodized aluminum alloys of high purity, resistances of $8.53 \times 10^{9} \Omega / \mathrm{cm}^{2}$ [92], while, in anodized aluminum alloy 2024 in mixtures of citric-sulfuric acid were found resistances between $1.38 \times 10^{5}$ and $2.44 \times 10^{5} \Omega / \mathrm{cm}^{2}$ [93]. Based on these results, it can be said that the hard anodizing of 6061 aluminum alloys can be carried out with solutions composed mainly of citric acid, reaching resistance values equal to or higher than those reported in the literature. The entry of chlorides towards the metallic substrate will be diminished when it has less porous and homogeneous surfaces, which improves the resistance to corrosion of aluminum alloys [94]. The different solutions used for the anodizing process in this work, composed of citric acid and small additions of sulfuric acids, effectively protect aluminum alloys against the effects of corrosion and attack by $\mathrm{Cl}^{-}$ions.

Table 4. EIS Data Obtained by Equivalent Electric Circuit Simulation of the AA 6061 Samples at Different Conditions.

\begin{tabular}{|c|c|c|c|c|c|c|c|c|c|c|}
\hline Sample & $\begin{array}{c}R_{s} \\
\left(\Omega \cdot \mathrm{cm}^{2}\right)\end{array}$ & $\begin{array}{c}\mathrm{CPE}_{\mathrm{p}} \\
\left(\Omega^{-1} \mathrm{~s}_{\mathrm{p}}^{\alpha} \mathrm{cm}^{-2}\right)\end{array}$ & $\begin{array}{c}R_{p} \\
\left(\Omega \cdot \mathrm{cm}^{2}\right)\end{array}$ & $\alpha_{p}$ & $\begin{array}{c}\mathrm{C}_{\mathrm{B}} \\
\left(\mathrm{F} / \mathrm{cm}^{2}\right)\end{array}$ & $\begin{array}{c}R_{B} \\
\left(\Omega \cdot \mathrm{cm}^{2}\right)\end{array}$ & $\alpha_{\mathrm{B}}$ & $\begin{array}{c}W_{B} \\
\left(\Omega \cdot \mathrm{cm}^{2} / \mathrm{s}^{0.5}\right)\end{array}$ & $\begin{array}{c}\text { Error } \\
(\%)\end{array}$ & $x^{2}$ \\
\hline AA 6061 & 21.61 & - & - & - & $6.84 \times 10^{-6}$ & $0.17 \times 10^{6}$ & 0.94 & - & $<2.58$ & $3 \times 10^{-2}$ \\
\hline 3A C0M S2M & 27.28 & - & - & - & $1.82 \times 10^{-9}$ & $3.90 \times 10^{6}$ & 0.83 & - & $<1.33$ & $1 \times 10^{-2}$ \\
\hline 3A C1M S5 & 14.17 & $0.46 \times 10^{-8}$ & $2.67 \times 10^{6}$ & 0.77 & $1.04 \times 10^{-9}$ & - & - & $8.63 \times 10^{6}$ & $<2.35$ & $8 \times 10^{-3}$ \\
\hline 3A C1M S10 & 26.34 & $0.94 \times 10^{-8}$ & $2.32 \times 10^{6}$ & 0.84 & $5.49 \times 10^{-9}$ & - & - & $20.60 \times 10^{6}$ & $<2.01$ & $3 \times 10^{-2}$ \\
\hline 3A C2M S5 & 14.99 & $7.40 \times 10^{-8}$ & $1.05 \times 10^{6}$ & 0.62 & $31.10 \times 10^{-9}$ & - & - & $23.90 \times 10^{6}$ & $<5.39$ & $1 \times 10^{-2}$ \\
\hline 3A C2M S10 & 18.85 & $85.30 \times 10^{-8}$ & $0.02 \times 10^{6}$ & 0.67 & $1.53 \times 10^{-9}$ & - & - & $3.20 \times 10^{6}$ & $<2.50$ & $3 \times 10^{-3}$ \\
\hline 4.5A C0M S2M & 15.20 & $0.44 \times 10^{-8}$ & $1.54 \times 10^{6}$ & 0.79 & $2.74 \times 10^{-9}$ & - & - & $2.40 \times 10^{6}$ & $<2.83$ & $1 \times 10^{-3}$ \\
\hline 4.5A C1M S5 & 24.73 & $7.18 \times 10^{-8}$ & $0.30 \times 10^{6}$ & 0.68 & $15.20 \times 10^{-9}$ & - & - & $3.32 \times 10^{6}$ & $<3.61$ & $2 \times 10^{-3}$ \\
\hline 4.5A C1M S10 & 35.38 & $5.03 \times 10^{-8}$ & $0.40 \times 10^{6}$ & 0.72 & $6.71 \times 10^{-9}$ & - & - & $3.00 \times 10^{6}$ & $<2.56$ & $2 \times 10^{-3}$ \\
\hline 4.5A C2M S5 & 42.74 & - & - & - & $228.00 \times 10^{-9}$ & $8.65 \times 10^{6}$ & 0.76 & - & $<1.73$ & $1 \times 10^{-2}$ \\
\hline 4.5A C2M S10 & 21.67 & $62.3 \times 10^{-8}$ & $0.04 \times 10^{6}$ & 0.70 & $551.00 \times 10^{-9}$ & - & - & $128.00 \times 10^{6}$ & $<3.55$ & $5 \times 10^{-3}$ \\
\hline
\end{tabular}

\section{Conclusions}

The coatings anodizing made with different solutions showed superficial cracks. However, the corrosion resistance was not affected due to the protection provided by the barrier layer formed.

AA6061 aluminum anodizing alloy has values of the thickness of 50 to $150 \mu \mathrm{m}$, which comply with MIL-A-8625F specification. 
The anodized samples in citric acid solutions presented Vickers microhardness greater than $340 \mathrm{HV}$ when manufactured with a current density of $3 \mathrm{~A} / \mathrm{dm}^{2}$. However, when the anodized current density was $4.5 \mathrm{~A} / \mathrm{dm}^{2}$, the microhardness presented values less than $300 \mathrm{HV}$ is lower than that obtained by conventional anodizing in sulfuric acid.

Cyclic potentiodynamic polarization technique indicated that higher $\mathrm{E}_{\mathrm{corr}}$, lower corrosion current densities ( $\left.\mathrm{i}_{\text {corr }}\right)$, and negative hysteresis was presented in most of the anodized samples. It represents that this hard anodization provides more excellent corrosion resistance than conventional sulfuric acid anodizing.

The EIS results showed that hard anodized coatings made with citric acid showed more excellent corrosion resistance when exposed to a corrosive $3.5 \mathrm{wt}$. $\% \mathrm{NaCl}$ solution.

The samples anodized in $2 \mathrm{M}$ citric acid solution and $10 \mathrm{~mL} / \mathrm{L}$ of sulfuric acid (C2M S10) with current densities of 3 and $4.5 \mathrm{~A} / \mathrm{dm}^{2}$ were those that presented the highest corrosion resistance in the evaluation medium.

Author Contributions: Conceptualization, J.C.-M., F.A.-C. and C.G.-T.; methodology, F.E.L. and M.L.B.; J.O.-C.; I.C.-R. data curation, J.C.-M., M.L.B., P.Z.-R. and M.Á.E.A.; L.D.L.-L.: formal analysis, J.C.-M., F.A.-C. and C.G.-T.; writing-review and editing, F.A.-C., J.C.-M. and C.G.-T. All authors have read and agreed to the published version of the manuscript.

Funding: This research was funded by the Mexican National Council for Science and Technology (CONACYT) of the projects A1-S-8882 and the Universidad Autónoma de Nuevo León (UANL).

Institutional Review Board Statement: Not applicable.

Informed Consent Statement: Not applicable.

Data Availability Statement: Not applicable.

Acknowledgments: The authors acknowledge The Academic Body UANL-CA-316 "Deterioration and integrity of composite materials" and the student M. Sc. Jesus Manuel Jaquez.

Conflicts of Interest: The authors declare no conflict of interest.

\section{References}

1. $\quad$ Evertsson, J.; Bertram, F.; Zhang, F.; Rullik, L.; Merte, L.R.; Shipilin, M.; Soldemo, M.; Ahmadi, S.; Vinogradov, N.; Carlà, F. The thickness of native oxides on aluminum alloys and single crystals. Appl. Surf. Sci. 2015, 349, 826-832. [CrossRef]

2. Nguyen, L.; Hashimoto, T.; Zakharov, D.N.; Stach, E.A.; Rooney, A.P.; Berkels, B.; Thompson, G.E.; Haigh, S.J.; Burnett, T.L. Atomic-scale insights into the oxidation of aluminum. ACS Appl. Mater. Interfaces 2018, 10, 2230-2235. [CrossRef] [PubMed]

3. Dumas, P.; Dubarry-Barbe, J.P.; Riviere, D.; Levy, Y.; Corset, J. Growth of thin alumina film on aluminum at room temperature: A kinetic and spectroscopic study by surface plasmon excitation. J. Phys. Colloq. 1983, 44, C10-205-C10-208. [CrossRef]

4. Wu, Y.; Zhao, W.; Wang, W.; Wang, L.; Xue, Q. Novel anodic oxide film with self-sealing layer showing excellent corrosion resistance. Sci. Rep. 2017, 7, 1-9.

5. Hagelsieb, L.M. Anodic Aluminum Oxide Processing, Characterization and Application to DNA Hybridization Electrical Detection. Ph.D. Thesis, Universite Catholique de Louvain, Louvain-La-Neuve, Belgique, 2007.

6. Sharma, A.K.; Bhojraj, H.; Kaila, V.K.; Narayanamurthy, H. Anodizing and inorganic black coloring of aluminum alloys for space applications. Met. Finish. 1997, 95, 14. [CrossRef]

7. Dasquet, P.C.; Caillard, D.; Conforto, E.; Bonino, J.P.; Bes, R. Investigation of the anodic oxide layer on 1050 and 2024 T3 aluminum alloys by electron microscopy and electrochemical impedance spectroscopy. Thin Solid Films 2000, 371, 183-190. [CrossRef]

8. Thompson, G.E. Porous anodic alumina: Fabrication, characterization and applications. Thin Solid Films 1997, $297,192-201$. [CrossRef]

9. Ofoegbu, S.U.; Fábio, A.; Fernandes, F.A.O.; Pereira, A.B. The sealing step in aluminum anodizing: A focus on sustainable strategies for enhancing both energy efficiency and corrosion resistance. Coatings 2020, 10, 226. [CrossRef]

10. Naoi, K.; Takeda, M.; Kanno, H.; Sakakura, M.; Shimada, A. Simultaneous electrochemical formation of Al2O3/polypyrrole layers (I): Effect of electrolyte anion in formation process. Electrochim. Acta 2000, 45, 3413-3421. [CrossRef]

11. Shang, Y.; Wang, L.; Niu, D.; Liu, Z.; Wang, Y.; Liu, C. Effects of additive for anodizing electrolyte on anodic film of high silicon aluminum alloy. Int. J. Electrochem. Sci. 2016, 11, 1549-1557.

12. Darwish, S. Anodization of aluminum in phosphate and carbonate solutions. Corrosion 1971, 27, 266-269. [CrossRef]

13. Kikuchi, T.; Nakajima, D.; Nishinaga, O.; Natsui, S.; Suzuki, R.O. Porous aluminum oxide formed by anodizing in various electrolyte species. Curr. Nanosci. 2015, 11, 560-571. [CrossRef]

14. Patra, N.; Salerno, M.; Losso, R.; Cingolani, R. Use of unconventional organic acids ass anodization electrolytes for fabrication of porous alumina. IEEE Nano 2009, 567-570. 
15. Kikuchi, T.; Nakajima, D.; Kawashima, J.; Natsui, S.; Suzuki, R.O. Fabrication of anodic porous alumina formed in malic acid solution. Appl. Suf. Sci. 2014, 313, 276-285. [CrossRef]

16. MIL-A-8625F. Anodic Coatings for Aluminum and Aluminum Alloys; Departments and Agencies of the Department of Defense: The Pentagon Arlington, VA, USA, 1993; pp. 1-19.

17. Edwards, J. Coating and Surface Treatment Systems for Metals; ASM International, Finishing Publications Ltd.: Naterials Park, OH, USA, 1994; Volume 38, pp. 35-40.

18. Gabe, D.R. Hard anodizing - What do we mean by hard? Met. Finish. 2002, 100, 52-58. [CrossRef]

19. Krishna, L.R.; Purnima, A.S.; Sundararajan, G. A comparative study of tribological behavior of microarc oxidation and hardanodized coatings. Wear 2006, 261, 1095-1101. [CrossRef]

20. Rajendra, A.; Biren, J.P.; Sharma, A.K.; Bhojraj, H.; Nayak, M.M.; Rajanna, K. Hard anodization of aluminium and its application to sensorics. Surf. Eng. 2005, 21, 193-197. [CrossRef]

21. Jiang, C.X.; Tu, J.P.; Guo, S.Y.; Fu, M.F.; Zhao, X.B. Friction properties of oil-in filtrated porous AAO film on an aluminium substrate. Acta Metallurgica Sinica Engl. Lett. 2005, 18, 249-253.

22. Lee, W. The anodization of aluminium for nanotechnology applications. JOM 2010, 62, 57-63. [CrossRef]

23. Choi, J. Fabrication of Monodomain Porous Alumina Using Nanoimprint Lithography and Its Applications. Ph.D. Thesis, Martin-Luther-Universitat Halle, Wittenberg, Germany, 2004.

24. Khan, I.U.; John, P.; Sheikh, S.T.; Gulzar, N.; Rehman, A.U. Anodizing of aluminum with improved corrosion properties. J. Chem. Soc. Pak. 2010, 32, 46-51.

25. Garcia-Vergara, S.J.; Skeldon, P.; Thompson, G.E.; Habazaki, H. A tracer investigation of chromic acid anodizing of aluminium. Surf. Interface Anal. 2007, 39, 860-864. [CrossRef]

26. Stępniowski, W.J.; Michalska-Domańska, M.; Norek, M.; Czujko, T. Fast Fourier transform based arrangement analysis of poorly organized alumina nanopores formed via self-organized anodization in chromic acid. Mater. Lett. 2014, 117, 69-73. [CrossRef]

27. Sulfuric Acid. Pubchem.ncbi.nlm.nih.gov. 2020. Retrieved 9 March 2020. Available online: https://pubchem.ncbi.nlm.nih.gov/ compound/Sulfuric-acid\#section=EPA-Safer-Chemical (accessed on 13 March 2020).

28. Schaedel, F.C. Sulfuric/organic electrolytes and total quality improvement (TQI) for present/future anodizing requirements. NASF Surf. Technol. 2017, 81, 1-17.

29. Norek, M.; Lazewski, M. Manufacturing of highly ordered porous anodic alumina with conical pore shape and tunable interpore distance in the range of $550 \mathrm{~nm}$ to $650 \mathrm{~nm}$. Mater. Sci. Pol. 2017, 35, 511-518. [CrossRef]

30. Koczera, A.E. The Effects of Carboxylic Acids in Aluminum Anodizing. Ph.D. Thesis, Honors Theses and Capstones, University of New Hampshire, Durham, NH, USA, 2017.

31. Citric Acid. Pubchem.ncbi.nlm.nih.gov. (2020). Retrieved 9 March 2020. Available online: https:/ / pubchem.ncbi.nlm.nih.gov/ compound/Citric-acid\#section=EPA-Safer-Chemical (accessed on 9 January 2020).

32. Wojciech, J.S.; Moneta, M.; Norek, M.; Michalska-Domańska, M.; Scarpellini, A.; Salerno, M. The influence of electrolyte composition on the growth of nanoporous anodic alumina. Electroch. Acta 2016, 211, 453-460.

33. Franco, M.; Krishna, T.H.; Pillai, A.M.; Rajendra, A.; Sharma, A.K. A comparative study on the corrosion behavior of hard anodic coatings on aa 6061 obtained using dc and pulsed dc power sources. Acta Metall. Sin. Engl. Lett. 2013, 26, 647-656. [CrossRef]

34. ASTM E3-95. Standard Practice for Preparation of Metallographic Specimens; ASTM International: West Conshohocken, PA, USA, 1995.

35. ASTM E407-07. Standard Practice for Microetching Metals and Alloys; ASTM International: West Conshohocken, PA, USA, 2011.

36. Huang, Y.L.; Shih, H.; Huang, H.C.; Daugherty, J.; Wu, S.; Ramanathan, S.; Chang, C.; Mansfeld, F. Evaluation of the corrosion resistance of anodized aluminum 6061 using electrochemical impedance spectroscopy (EIS). Corros. Sci. 2008, 50, 3569-3575. [CrossRef]

37. Zuo, Y.; Zhao, P.H.; Zhao, J.M. The influences of sealing methods on corrosion behavior of anodized aluminum alloys in NaCl solutions. Surf. Coat. Technol. 2003, 166, 237-242. [CrossRef]

38. Suay, J.J.; Gimenez, E.; Rodriguez, T.; Habbib, K.; Saura, J.J. Characterization of anodized and sealed aluminium by EIS. Corros. Sci. 2003, 45, 611-624. [CrossRef]

39. Cabral-Miramontes, J.A.; Barceinas-Sánchez, J.D.O.; Poblano-Salas, C.A.; Pedraza-Basulto, G.K.; Nieves-Mendoza, D.; ZambranoRobledo, P.C.; Almeraya-Calderón, F.; Chacón-Nava, J.G. Corrosion Behavior of AISI 409Nb Stainless Steel Manufactured by Powder Metallurgy Exposed in $\mathrm{H}_{2} \mathrm{SO}_{4}$ and $\mathrm{NaCl}$ Solutions. Int. J. Electrochem. Sci. 2013, 8, 564-577.

40. Cabral Miramontes, J.A.; Barceinas Sánchez, J.D.O.; Almeraya Calderón, F.; Martínez Villafañe, A.; Chacón Nava, J.G. Effect of Boron Additions on Sintering and Densification of a Ferritic Stainless Steel. J. Mater. Eng. Perform. 2010, 19, 880-884. [CrossRef]

41. ASTM G5-11. Standard Reference Test Method for Making Potentiostatic and Potentiodynamic Anodic Polarization Measurements; ASTM International: West Conshohocken, PA, USA, 2011.

42. ASTM G106-15. Standard Practice for Verification of Algorithm and Equipment for Electrochemical Impedance Measurements; ASTM International: West Conshohocken, PA, USA, 2015.

43. Setyarini, P.H.; Soenoko, R.; Suprapto, A.; Irawan, Y.S. Effect of low potential anodizing of AA 6061. J. Eng. Appl. Sci. 2017, 12, 6419-6422.

44. Gilling, F.G. WADC Technical Report, Study of Hard Coating for Aluminum Alloys; Cornell Aeronautical Laboratory, Wright Air Development Center, Wright-Patterson Air Force Base: Dayton, OH, USA, 1987; pp. 53-151. 
45. Military Handbook, MIL_HDBK-132A (ORD), Department of the Army Technical Bulletin TB-700-801D-1, Chapter 5: Electrochemical conversion coatings (anodic coatings). In Protective Finishes for Metal and Wood Surfaces; Federal and Military Specification and Standars are Government Publications; The Naval Publication and Dorms Center: Philadelphia, PA, USA, 1984; pp. 83-100.

46. López, V.; Otero, E.; Bautista, A.; González, J.A. Sealing of anodic films obtained in oxalic acid baths. Surf. Coat. Technol. 2000, 124, 76-84. [CrossRef]

47. Van Der Linden, B.; Terryn, H.; Vereecken, J. Investigation of anodic aluminium oxide layers by electrochemical impedance spectroscopy. J. Appl. Electrochem. 1990, 20, 798-803. [CrossRef]

48. Moutarlier, V.; Gigandet, M.P.; Ricq, L.; Pagetti, J. Electrochemical characterization of anodic oxidation films formed in presence of corrosion inhibitors. Appl. Surf. Sci. 2001, 183, 1-9. [CrossRef]

49. Schneider, M.; Liebmann, T.; Langklotz, U.; Michaelis, A. Microelectrochemical investigation of anodic oxide formation on the aluminum alloy AA2024. Electrochim. Acta 2017, 249, 198-205. [CrossRef]

50. Peng, L.; Li, M. Improved technology for hard anodizing dissolution of aluminum alloy part. The Open Mat. Sci. J. 2015, 9, 82-85. [CrossRef]

51. Chu, S.Z.; Wada, K.; Inoue, S.; Isogai, M.; Yasumori, A. Fabrication of ideally ordered nanoporous alumina films and integrated alumina nanotubule arrays by high-field anodization. Adv. Mater. 2005, 17, 2115-2119. [CrossRef]

52. Schwirn, K.; Lee, W.; Hillebrand, R.; Steinhart, M.; Nielsch, K.; Gösele, U. Self-ordered anodic aluminum oxide formed by H2SO4 hard anodization. ACS Nano 2008, 2, 302-310. [CrossRef]

53. Noh, K.; Brammer, K.; Kim, H.; Jung, S.; Seong, T.; Jin, S. Highly self-assembled nanotubular aluminum oxide by hard anodization. J. Mater. Res. 2011, 26, 186-193. [CrossRef]

54. Lerner, L.M. Hard anodizing of aerospace aluminium alloys. Trans. Inst. Met. Finish. 2010, 88, 21-24. [CrossRef]

55. Kwolek, P.; Krupa, K.; Obłój, A.; Kocurek, P.; Wierzbin’ska, M.; Sieniawski, J. Tribological Properties of the Oxide Coatings Produced onto 6061-T6 Aluminum Alloy in the Hard Anodizing Process. J. Mater. Eng. Perform. 2018, 27, 3268-3275. [CrossRef]

56. Kwolek, P. Hard anodic coatings on aluminum alloys. Adv. Manuf. Sci. Tech. 2017, 41, 35-46.

57. Thomas, R.W. Hard Anodizing of Aluminum; Brace, A.W., Ed.; Technicopy Ltd.: Stonehouse, UK, 1987; pp. 1-7.

58. Wang, L.W.; Tian, H.Y.; Gao, H.; Xie, F.Z.; Zhao, K.; Cui, Z.Y. Electrochemical and XPS analytical investigation of the accelerative effect of bicarbonate/carbonate ions on AISI 304 in alkaline environment. Appl. Surf. Sci. 2019, 492, 792-807. [CrossRef]

59. Yang, Y.J.; Zhang, Z.P.; Jin, Z.S.; Sun, W.C.; Xia, C.Q.; Ma, M.Z.; Zhang, X.Y.; Li, G.; Liu, R.P. A study on the corrosion behavior of the in-situ Ti-based bulk metallic glass matrix composites in acid solutions. J. Alloys Compd. 2019, 782, 927-935. [CrossRef]

60. Khamaj, J.A. Cyclic polarization analysis of corrosion behavior of ceramic coating on $6061 \mathrm{Al} / \mathrm{SiCp}$ composite for marine applications. Prot. Met. Phys. Chem. Surf. 2016, 52, 886-893. [CrossRef]

61. Loto, R.T.; Adeleke, A.J. Corrosion of Aluminum Alloy Metal Matrix Composites in Neutral Chloride Solutions. Failure Anal. Prev. 2016, 16, 874-885. [CrossRef]

62. Silverman, D.C. Practical Corrosion Prediction Using Electrochemical Techniques, 3rd ed.; John Wiley \& Sons, Inc.: Hoboken, NJ, USA, 2011; pp. 1129-1166. [CrossRef]

63. McCafferty, E. Introduction to Corrosion Science; Springer: New York, NY, USA, 2010.

64. El-Hameed, A.M.A.; Abdel-Aziz, Y.A.; El-Tokhy, F.S. Anodic Coating Characteristics of Different Aluminum Alloys for Spacecraft Materials Applications. J. Mater. Sci. Appl. 2017, 8, 197-208. [CrossRef]

65. Arredondo-Rea1, P.S.; Corral-Higuera, R.; Neri-Flores, M.A.; Gómez-Soberón, J.; Almeraya-Calderón, F.; Castorena-González, K.H.; Almaral-Sánchez, J.L. Electrochemical Corrosion and Electrical Resistivity of Reinforced Recycled Aggregate Concrete. Int. J. Electrochem. Sci. 2011, 6, 475-483.

66. Jalal, H.; Hussein, K.; Karabet, F.; Saound, Y. Study of the effect mechanism of organic additives on the aluminum alloy 6066 anodization. J. Miner. Met. Mater. Eng. 2019, 5, 73-81.

67. Sposito, G. The Environmental Chemistry of Aluminum, 2nd ed.; CRC Press: Boca Raton, FL, USA, 1996; pp. 173-174, $303-305$.

68. Hidber, P.C.; Graule, T.J.; Gauckler, L.J. Citric Acid-A Dispersant for Aqueous Alumina Suspensions. J. Am. Ceram. Soc. 1996, 79, 1857-1867. [CrossRef]

69. Wieland, E.; Stumm, W. Dissolution kinetics of kaolinite in acidic aqueous solutions at $25^{\circ}$ C. Geochim. Acta 1992, 56, 3339-3355. [CrossRef]

70. Šeruga, M.; Hasenay, D. Electrochemical and surface properties of aluminium in citric acid solutions. J. Appl. Electrochem. 2001, 31, 961-967. [CrossRef]

71. Huang, Y.; Esra, K.; Mansfeld, F. Evaluation of the corrosion resistance of anodizing aluminum samples using electrochemical impedance spectroscopy. In Proceedings of the Annual Graduate Student Research Symposium, Los Angeles, CA, USA; 2007.

72. Corral, H.R.; Arredondo, R.S.P.; Neri, F.M.; Gómez, S.J.M.; Almeraya, C.F.; Castorena, G.J.H.; Almaral, S.J. Sulfate attack and reinforcement corrosion in concrete with recycled concrete aggregates and supplementary cementing materials. Int. J. Electrochem. Sci. 2011, 6, 613-621.

73. Cabral-Miramontes, J.A.; Gaona-Tiburcio, C.; Almeraya-Calderón, F.; Estupiñan-Lopez, H.F.; Pedraza-Basulto, G.; Poblano-Salas, C. Parameter Studies on High-Velocity Oxy-Fuel Spraying of CoNiCrAlY Coatings Used in the Aeronautical Industry. Int. J. Corros. 2014, 703806, 1-8. [CrossRef] 
74. Dzhurinskiy, D.V.; Dautov, S.S.; Shornikov, P.G.; Akhatov, I.S. Surface Modification of Aluminum 6061-O Alloy by Plasma Electrolytic Oxidation to Improve Corrosion Resistance Properties. Coatings 2021, 11, 4. [CrossRef]

75. Ryu, H.S.; Mun, S.-J.; Lim, T.S.; Kim, H.-C.; Shin, K.-S.; Hong, S.-H.; Tanasini, P.; Diethelm, S.; Van Herle, J.; Favrat, D. Microstructure evolution during plasma electrolytic oxidation and its effects on the electrochemical properties of AZ91D Mg alloy. J. Electrochem. Soc. 2011, 158, 266-273. [CrossRef]

76. Domingues, L.; Fernandes, J.C.S.; Belo, M.D.C.; Ferreira, M.G.S.; Guerra-Rosa, L. Anodizing of Al 2024-T3 in a modified sulphuric acid/boric acid bath for aeronautical applications. Corros. Sci. 2003, 45, 149-160. [CrossRef]

77. Analysis of Alternatives for Chromium Sealing in the Aerospace Industry-GCCA_AoA_Potassium Dichromate-2007. Available online: https: / / echa.europa.eu/documents/10162/d6c88cd1-ef18-460b-8493-e1d59211a888 (accessed on 5 November 2019).

78. Mansfeld, F.; Shih, H.; Greene, H.; Tsai, C.H. Analysis of EIS-data for common corrosion processes. In Electrochemical Impedance: Analysis and Interpretation, ASTM STP 1188; Scully, J.R., Silverman, D.D., Kendig, M.W., Eds.; ASTM: San Diego, CA, USA, 1991. [CrossRef]

79. MacDonald, J.R.; Johnson, W.B. Impedance Spectroscopy; John Wiley \& Sons, Inc.: Hoboken, NJ, USA, 1987 ; pp. $154-156$.

80. Fonseca, C.; Barbosa, M.A. Corrosion behaviour of titanium in biofluids containing $\mathrm{H} 2 \mathrm{O} 2$ studied by electrochemical impedance spectroscopy. Corros. Sci. 2001, 43, 547-559. [CrossRef]

81. Macdonald, D. Reflections on the history of electrochemical impedance spectroscopy. Electrochim. Acta 2006, 51, 1376-1388. [CrossRef]

82. Liu, J.C.; Park, S.W.; Nagao, S.J.; Nogi, M.; Koga, H.; Ma, J.S. The role of Zn precipitates and Cl anions in pitting corrosion of Sn-Zn solder alloys. Corros. Sci. 2015, 92, 263-271. [CrossRef]

83. Cabral-Miramontes, J.; Gaona-Tiburcio, C.; Estupinán-López, F.; Lara-Banda, M.; Zambrano-Robledo, P.; Nieves-Mendoza, D.; Maldonado-Bandala, E.; Chacón-Nava, J.; Almeraya-Calderón, F. Corrosion Resistance of Hard Coat Anodized AA 6061 in Citric-Sulfuric Solutions. Coatings 2020, 10, 601. [CrossRef]

84. Khadiri, M.; Elyaagoubi, M.; Idouhli, R.; Koumya, Y.; Zakir, O.; Benzakour, J.; Benyaich, A.; Abouelfida, A.; Outzourhit, A. Electrochemical Study of Anodized Titanium in Phosphoric. Acid. Adv. Mater. Sci. Eng. 2020, 2020, 1-11. [CrossRef]

85. Macdonald, D.D. Review of mechanistic analysis by electrochemical impedance spectroscopy. Electrochim. Acta 1990, 35, 1509-1525. [CrossRef]

86. Cesiulis, H.; Tsyntsaru, N.; Ramanavicius, A.; Ragoisha, G. The Study of Thin Films by Electrochemical Impedance Spectroscopy. Chapter, I. In Nanostructures and Thin Films for Multifunctional Applications; Tiginyanu, I., Topala, P., Ursaki, V., Eds.; NanoScience and Technology; Springer: Berlin/Heidelberg, Germany, 2016. [CrossRef]

87. Kramer, G.R.; Mendez, C.M.; Ares, A.E. Evaluation of corrosion resistance of aluminum-based alloys in bioethanol produced in Misiones. Proc. Mat. Sci. 2015, 9, 341-349. [CrossRef]

88. Narayanan, R.; Seshadri, S.K. Phosphoric acid anodization of Ti-6Al-4V-Structural and corrosion aspects. Corros. Sci. 2007, 49, 542-558. [CrossRef]

89. Shao, L.; Li, H.; Jiang, B.; Liu, C.; Gu, X.; Chen, D. A Comparative Study of Corrosion Behavior of Hard Anodized and Micro-Arc Oxidation Coatings on 7050 Aluminum Alloy. Metals 2018, 8, 165. [CrossRef]

90. Ban, C.L.; He, Y.D.; Xin, S. Effect of citric acid on microstructure and electrochemical characteristics of high voltage anodized alumina film formed on etched Al Foils. Trans. Nonferrous Met. Soc. China 2011, 21, 133-138. [CrossRef]

91. Xiangfeng, M.; Guoying, W.; Hongliang, G.; Yundan, Y.; Ying, C.; Dettinger, H. Anodization for 2024 Al Alloy from Sulfuric-Citric Acid and Anticorrosion Performance of Anodization Films. Int. J. Electrochem. Sci. 2013, 8, 10660-10671.

92. Tang, C.W. The Study of Anodic Treatment of Aluminum in Tertiary Mixed Acid after High Temperature Pre-Immersing. Ph.D. Thesis, Tatung University, Taipei City, Taiwan, 2005.

93. Martinez-Villafañe, A.; Chacon-Nava, J.G.; Gaona-Tiburcio, C.; Almeraya-Calderon, F.; Domínguez-Patiño, G.; GonzalezRodríguez, G. Oxidation performance of a Fe-13Cr alloy with additions of rare earth elements. Mater. Sci. Eng. A 2003, 363, 15-19. [CrossRef]

94. Gaona-Tiburcio, C.; Montoya, R.M.; Cabral, M.J.A.; Estupiñan, L.F.; Zambrano, R.P.; Orozco, C.R.; Chacon-Nava, J.G.; Baltazar, Z.M.A.; Almeraya-Calderon, F. Corrosion resistance of multilayer coatings deposited by PVD on inconel 718 using electrochemical impedance spectroscopy technique. Coatings 2020, 10, 521. [CrossRef] 